\title{
Mechanism of manganese oxidization of Bacillus safensis strain ST7 isolated from the soil of mineral area
}

\section{XQ Ran}

Guizhou University https://orcid.org/0000-0002-5083-739X

Hong Long

Guizhou Minzu University

Qun Tian

Guizhou University

Jiafu Wang ( $\nabla$ jfwang@gzu.edu.cn )

Guizhou University https://orcid.org/0000-0003-2893-3200

\section{Longjiang You}

Guizhou University

\section{Shihui Huang}

Guizhou University

Xi Niu

Guizhou University

Sheng Li

Guizhou University

\section{Research}

Keywords: Bacillus sanfensis, Manganese oxidation, Manganese mine, transcriptome, differently expressed genes

Posted Date: July 28th, 2020

DOl: https://doi.org/10.21203/rs.3.rs-46834/v1

License: (c) (i) This work is licensed under a Creative Commons Attribution 4.0 International License. Read Full License 
Mechanism of manganese oxidization of Bacillus safensis strain ST7 isolated from the soil of mineral area

Xueqin Ran ${ }^{1}$, Hong Long ${ }^{1}$, Qun Tian ${ }^{1}$, Jiafu Wang ${ }^{1, *}$, Longjiang You ${ }^{1}$, Shihui Huang ${ }^{1}$, Xi Niu ${ }^{1}$, Sheng $\mathrm{Li}^{1}$

${ }^{1}$ College of Animal Science, Institute of Agro-Bioengineering, Guizhou University, Guiyang 550025, China

$\begin{array}{ll}\text { Xueqin Ran } & \text { xqran@gzu.edu.cn } \\ \text { Hong Long } & \text { 1599253955@qq.com } \\ \text { Qun Tian } & \text { 1657070829@qq.com } \\ \text { Jiafu Wang } & \text { jfwang@gzu.edu.cn } \\ \text { Longjiang You } & \text { 986755605@qq.com } \\ \text { Shihui Huang } & \text { 359151287@qq.com } \\ \text { Xi Niu } & \text { 372724002@qq.com } \\ \text { Sheng Li } & \text { listen318@163.com }\end{array}$


Mechanism of manganese oxidization of Bacillus safensis strain ST7 isolated from the soil of mineral area

Xueqin Ran ${ }^{1}$, Hong Long ${ }^{1}$, Qun Tian ${ }^{1}$, Jiafu Wang ${ }^{1,}{ }^{*}$, Longjiang You ${ }^{1}$, Shihui Huang ${ }^{1}$, Xi Niu ${ }^{1}$, Sheng $\mathrm{Li}^{1}$

\begin{abstract}
Background: The manganese pollution is very serious surrounding the mine area, which could be enriched and harmful to animal, plant and human. Manganese oxidation bacteria (MOB) can completely remove the toxicity of $\mathrm{Mn}(\mathrm{II})$ with diverse mechanisms.
\end{abstract}

Results: To seek a resource and disclose the oxidation mechanism of MOB, we isolated the Bacillus safensis strain ST7 from the soil of Songtao manganese mine in Guizhou province, China. Strain ST7 could survive in media containing $2200 \mathrm{mg} / \mathrm{L} \mathrm{Mn}(\mathrm{II})$ with the $\mathrm{Mn}(\mathrm{II})$ removal efficiency of $82 \%$ after seven days cultivation. The rate was $7.75 \mu \mathrm{mol} / \mathrm{L}$ of $\mathrm{Mn}(\mathrm{II})$ each day detected by LBB method. The manganese oxides appeared after stationary growth phase and lots of irregular precipitates were observed on the surface of bacteria by scanning electron microscopy (SEM). We further constructed eight cDNA libraries at two growth stages of strain ST7, at which the first stage is the mid-exponential growth phase (stage1) and the second one at the onset of stationary phase (stage2). The gene expression patterns were analyzed across the entire transcriptome under $250 \mathrm{mg} / \mathrm{L} \mathrm{Mn(II)} \mathrm{stress} \mathrm{by} \mathrm{using} \mathrm{Illumina} \mathrm{Hiseq} \mathrm{platform.}$ After mapping to the reference $B$. safensis genome, we detected 3574 expressed genes from the eight libraries. At the first stage, 1040 differently expressed genes (DEGs) were determined with 502 genes up-regulated in $\mathrm{Mn}(\mathrm{II})$ dealt group. For the second stage, 760 genes were increased and 702 genes down-regulated under $\mathrm{Mn}$ (II) stress. Of those, the expressed trend of seventeen random selective genes were confirmed by RT-qPCR method. Only nine high expressed DEGs were screened out and all of them were up-regulated in the manganese dealt group at stage 1 . The great changes at stage 1 were focused on the genes related with siderophore synthesis to help $\mathrm{Mn}(\mathrm{II})$ uptake and oxidation and gene che $A$ to elevate the chemotaxis and the motility of bacteria. It was observed that the motility of strain ST7 was much active in the media with $\mathrm{Mn}$ (II) supply. And the expression level of gene601, coded for a multicopper oxidase (MCO) enzyme-like protein, raised about 3.66 times than its control group at stage 1. By using homologous recombination technology, it was demonstrated that the $\mathrm{Mn}(\mathrm{II})$ oxidase ability decreased obviously when the gene601 of B. safensis strain ST7 was knocked out. For stage 2 of strain 
ST7 dealt with $\mathrm{Mn}(\mathrm{II})$, there were nineteen genes related with sporulation and most of flagellum genes were inhibited. However, lots of transporters genes were augmented to function as pumps to extrude manganese outside of the bacterium cell.

Conclusions: In a brief, the isolated $B$. sanfensis took two strategies against $\mathrm{Mn}$ stress including manganese oxidation at exponential growth stage and transformation of $\mathrm{Mn}(\mathrm{II})$ at stationary phase. The strain could be used to treat the environmental manganese pollution to minimize the use of chemical oxidants as a cost-effective technology.

Keywords: Bacillus sanfensis, Manganese oxidation, Manganese mine, transcriptome, differently expressed genes

\section{Background}

Manganese $(\mathrm{Mn})$ is an essential trace element for all living life. It is constituent in photosystem II of plant and an essential cofactor in the active centers of enzymes, including oxidoreductases, transferases, ligases, and hydrolases [1-3]. It participates processes of redox reaction, ATP synthesis, fat and carbohydrate metabolisms, protein modification, and is needed for processes of development, functions of both nerve and immune cells, control of blood sugar and vitamin level in animals, photosynthesis and respiration in plants $[4,5]$. However, $\mathrm{Mn}$ can be toxic to many organs and retain for a long time in human body during a long time of over-exposure [6]. Taking of food or drinking water possessed a high level of Mn causes potential undesirable effects on human health (for a review, see reference [6]. Manganese could accumulate and be toxic substantially in human ancreas, bone, kidney, liver, adrenal and pituitary glands, with a half-life as high as eight to nine years estimated in bones. Mn toxicity has been associated with dopaminergic dysfunction and related with Parkinson's or Alzheimer's disease $[7,8]$.

Excessive manganese in animal and plant mainly resulted from the high level of manganese in the environment. The main channel of Mn absorption from environment is through the digestive and respiratory tracts of animal [9]. Of seven valence states of manganese, the dominant states are $\mathrm{Mn}(\mathrm{II})$, $\mathrm{Mn}(\mathrm{III})$ and $\mathrm{Mn}(\mathrm{IV})$ oxides in the environment. Oxides of $\mathrm{Mn}(\mathrm{III})$ and $\mathrm{Mn}(\mathrm{IV})$ are insoluble in water. Thus, $\mathrm{Mn}$ (II) oxide is the main toxic form to life, which is soluble and could move along with water or food chains and accumulated into living cells. The safety standard for drinking water is $0.1 \mathrm{mg} / \mathrm{L}$ in China. The other states of $\mathrm{Mn}$ in surrounding and soil can be transformed into $\mathrm{Mn}(\mathrm{II})$, and easily filtered into the ground water resulting in the high concentration of $\mathrm{Mn}$ in ground water. Growing numbers of countries 
report that the Mn concentrations in ground water is exceeding the permitted limits, including China, Austria, the United States etc [10].

There is no doubt that the water or river near mining processing plant have high level of $\mathrm{Mn}(\mathrm{II})$. The dominant contamination originated from mining and metal smelting industries. In China, the abundant manganese reserves and the largest manganese industries gathered in the border area of three provinces, known as the "manganese triangle", which located in the northeast of Guizhou, northwest of Hunan province, southeast of Chongqing city. In 2007, it produced 178.62 tons of manganese in China, accounting for almost $98.4 \%$ of the total global production yield. The average content of manganese in the soil of abandoned land of Xiangtan Manganese Mine, Hunan provcine of China, is $20041.3 \mathrm{mg} / \mathrm{kg}$, about 34.38 times more than the national background value in China.The situation is so serious that nearly half of the water sources fail to meet the drinking water standard, especially in Guizhou province, China. The manganese pollution has impacted on the growth and development of some children surrounding those mine areas. For a high concentration of manganese, chemical methods, such as filter of manganese sand, are often used to remove manganese in waste water from mine factories. In natural world, not all of $\mathrm{Mn}(\mathrm{II})$ could be oxidized into $\mathrm{Mn}(\mathrm{III})$ or $\mathrm{Mn}(\mathrm{IV})$ by oxygen and it is impossible for these manganese metal is eliminated completely by the way of sedimentation and aeration. And manganese pollution in a low concentration need microorganism to remove thoroughly. Many kinds of bacteria can transform thoroughly the $\mathrm{Mn}(\mathrm{II})$ to its oxides [11]. It is reported that kinds of manganese-oxidizing bacteria $(\mathrm{MOB})$ harbour multicopper oxidase (MCO)-type enzyme or heme peroxidase $[12,13]$ with the capacity of oxidization the soluble $\mathrm{Mn}(\mathrm{II})$ to insoluble $\mathrm{Mn}(\mathrm{IV})$. MOB can elevate the $\mathrm{Mn}(\mathrm{II})$ removal efficiency by about five folds $[14,15]$. Nevertheless, it appear that the details of the mechanisms why bacteria are able to catalyze the oxidation of manganese might be diverse and remain largely unknown $[16,17]$. In the present work, we isolated a strain of $\mathrm{MOB}$ from the soil of manganese mine and investigated its transcriptome profiles under high level of manganese stress.

\section{RESULTS}

\section{Isolation of MOB and detection of manganese oxidation capacity}

To separate MOB strains with high ability, soil was sampled from an abandoned manganese mine located in Guizhou, China. A total of seven bacteria strains were isolated. After training, the strain ST7 appeared the highest Mn(II) oxidation capacity, which could grow on media containing $2200 \mathrm{mg} / \mathrm{L} \mathrm{Mn}(\mathrm{II})$ 
with the Mn removal efficiency of $82 \%$. Based on the characteristics of dye LBB specifically oxidized by $\mathrm{Mn}(\mathrm{III})$ and $\mathrm{Mn}(\mathrm{IV})[18,19]$, the oxide formation of $\mathrm{Mn}(\mathrm{III} / \mathrm{IV})$ was further observed that a blue colour appeared on the colonies of strain ST7 grown on solid media supplied with $250 \mathrm{mg} / \mathrm{L} \mathrm{MnCl} 2$ while the blue colour was much deeper on the plate contained $2200 \mathrm{mg} / \mathrm{MnCl} 2$ (Fig. 1). Qualitative test for $\mathrm{Mn}$ (III, IV) oxide in liquid cultures gave the similar results (Fig. 2). The capacity of strain ST7 was 7.75 $\mu \mathrm{mol} /($ L.d). Moreover, lots of irregular precipitates covered on the surface of bacteria could be visualized by SEM after incubated for seven days in $2200 \mathrm{mg} / \mathrm{L} \mathrm{MnCl} 2$ liquid media (Fig. 3B).

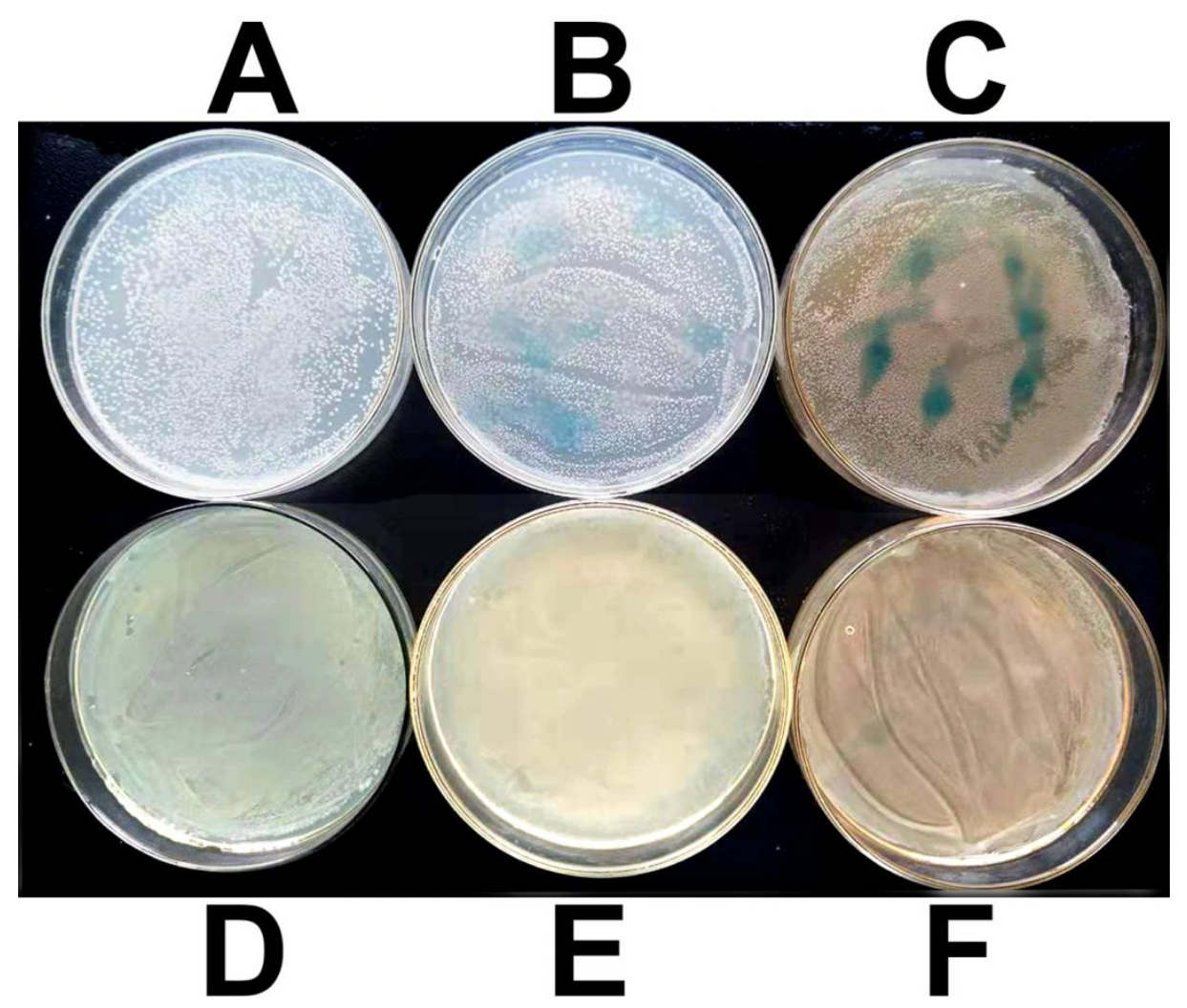

Fig. 1 The oxidation capacity of Mn(II) by strain ST7 detected by LBB method.

The colonies of strain ST7 and Staphyloccocus aureus were incubated for seven days at $28^{\circ} \mathrm{C}$, about 150 uL $0.04 \%$ LBB were spread onto each plate. A: Strain ST7 cultured on PYCM solid plate. B: Strain ST7 cultured on PYCM plate with $250 \mathrm{mg} / \mathrm{L} \mathrm{MnCl}_{2}$ produced faint blue blocks. C: Strain ST7 cultured on PYCM plate with $2200 \mathrm{mg} / \mathrm{L} \mathrm{MnCl}$. Several stripes in deep blue colour could be clearly observed on the plate. D: Staphyloccocus aureus Rosenbach cultured on solid LB media. E: Staphyloccocus aureus Rosenbach cultured on LB plate with $250 \mathrm{mg} / \mathrm{L} \mathrm{MnCl}_{2}$. F: Staphyloccocus aureus Rosenbach cultured on LB plate with $2200 \mathrm{mg} / \mathrm{L} \mathrm{MnCl}$. 


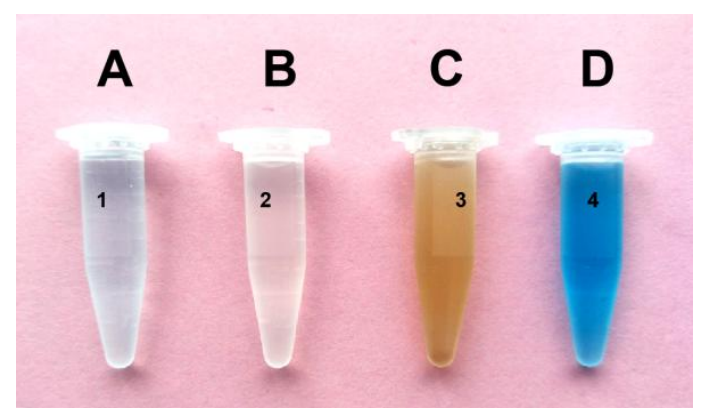

Fig. 2 The oxidation of strain ST7 in liquid medium detected by LBB solution.

Strain ST7 was grown in PYCM media for 7 days at $28^{\circ} \mathrm{C}$, adding $150 \mathrm{uL}$ of $0.04 \%$ LBB into each tube. A: LBB solution. B: cultures of strain ST7. C: cultures of strain ST7 with $250 \mathrm{mg} / \mathrm{L} \mathrm{MnCl} 2$ with the $\mathrm{Mn}$ oxides in brown color. D: LBB solution was added into the cultures of strain ST7 with $250 \mathrm{mg} / \mathrm{L} \mathrm{MnCl}$.
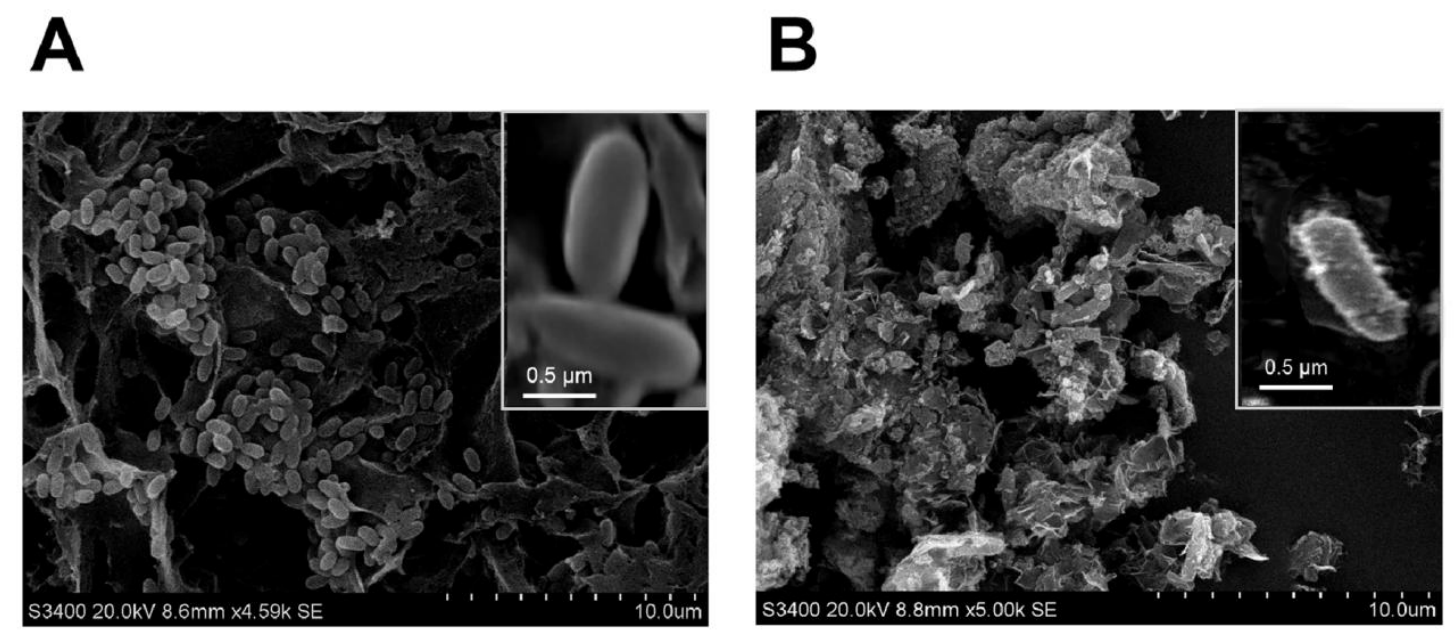

Fig. 3 The precipitates of manganese oxides outside of bacteria by SEM observation.

The strain ST7 bacteria were cultivated for seven days in PYCM liquid media without Mn(II) (A) or supplied with $2200 \mathrm{mg} / \mathrm{L} \mathrm{MnCl}_{2}$ (B).

\section{The motility of strain ST7}

Base on the puncture experiment, the strain ST7 present motility capacity under $250 \mathrm{mg} / \mathrm{L}$ $\mathrm{Mn}$ (II) stress (Fig. 4B). The colonies spread about two times in diameter when the strain ST7 was placed on soft-agar plate supplied with $250 \mathrm{mg} / \mathrm{L} \mathrm{Mn(II)} \mathrm{(Fig.} \mathrm{4D).} \mathrm{It} \mathrm{indicated} \mathrm{that}$ the motility of strain ST7 could be stimulated by manganese. 


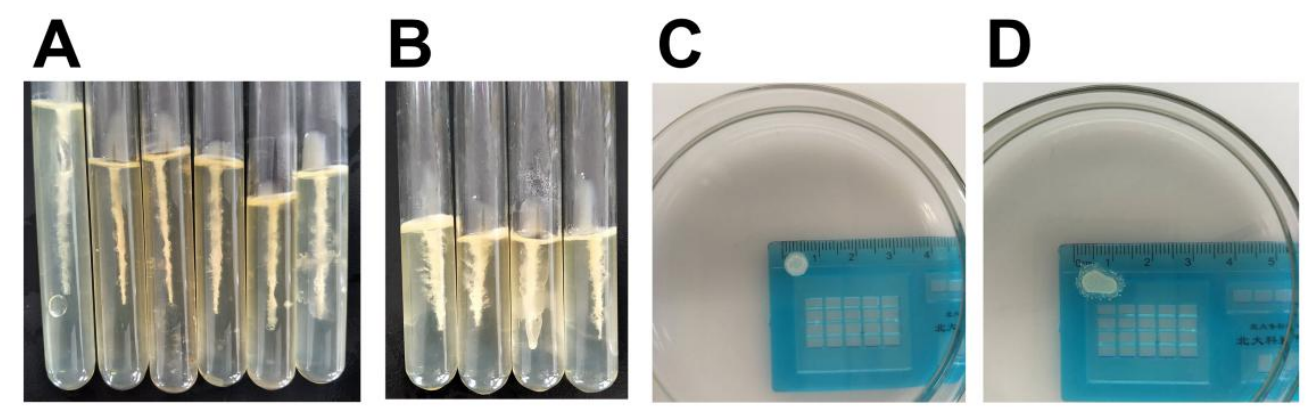

Fig. 4 Detection for the motility of bacteria ST7 under manganese stress.

A: Punctured tube of strain ST7 without Mn(II) supply. B: Punctured tube of strain ST7 with $250 \mathrm{mg} / \mathrm{L}$ Mn(II). C: Soft-agar plate of strain ST7 without Mn(II) supply. D: Soft-agar plate of strain ST7 with 250 $\mathrm{mg} / \mathrm{L} \mathrm{Mn(II)}$

\section{Identification for strain ST7}

Strain ST7 was positive in Gram-staining (Fig. S1), and able to produce ornithine decarboxylase, catalase, and $\mathrm{H}_{2} \mathrm{~S}$, but not to produce lysine decarboxylase, $\beta$-galactosidase. The citrate test was positive but both of Voges-Proskauer test and methyl red (MR) test were negative. The bacteria ST7 could hydrolyze glucose, gelatin and malonate. Acid from ethanol, dulcitpl, sorbitol and starch is negative. The evaluated characteristics coincided with the records of Bacillus sp. in the Bergey's Manual of Systematic Bacteriology.

The 16S rRNA gene fragments were amplified using the genome extracted from strain ST7. Then, the PCR products with 1421 bp in length were obtained and sequenced. Based on BLAST searching with the related sequences deposited in the nucleotide database of NCBI, the phylogenetic tree were constructed using MEGA7 [20]. Based on nucleotide similarity of 16S rRNA gene sequence, the isolated strain ST7 was clustered with Bacillus safensis and Bacillus pumilus in the phylogenetic tree (Fig. S2A). It might be the reason that both species are too much close to distinguish from each other just based on the $16 \mathrm{~S}$ rRNA gene similarity [21-23]. Another evolutionary analyse was further built based on gene6 sequence encoded DNA gyrase subunit A (gryA). The nucleotide sequence ( $2505 \mathrm{nt}$ ) of gene6 from strain ST7 could be clustered with the known sequences from all of Bacillus safensis with identity of 97.41-99.72\% while it was less than $92.53 \%$ with Bacillus pumilus and the other Bacillus species (Fig. S2B). Taken together, the strain ST7 was identified as Bacillus safensis according to the phenotypic and biochemical characteristics and sequence similarities of both 16S rRNA and gryA genes. 


\section{Expression profile of transcriptome of $B$. safensis strain ST7}

\section{Concentration of $\mathrm{Mn}(\mathrm{II})$ stress}

The strain ST7 grew fast in the PYCM medium without manganese (Fig. 5). It reached the mid-exponential phase cultured for 8 hs and the onset of stationary phase needed 12 hs. When the strain was cultured in media supplied with $2200 \mathrm{mg} / \mathrm{L} \mathrm{MnCl}_{2}$, the growth was inhibited obviously reaching to the onset of stationary phase after $44 \mathrm{hs}$. Compared with the control group, the growth rate decreased about $50 \%$ by the stress of $250 \mathrm{mg} / \mathrm{L} \mathrm{MnCl}_{2}$, in which the mid-exponential phase appeared in $16 \mathrm{hs}$ and the stationary phase started at 24 hs. To balance a higher response on the manganese stress and the growth velocity of bacteria, the $\mathrm{ED}_{50}$ of $\mathrm{Mn}(\mathrm{II})$ of $250 \mathrm{mg} / \mathrm{L}$ was taken as the concentration used for transcriptome RNA-Seq.

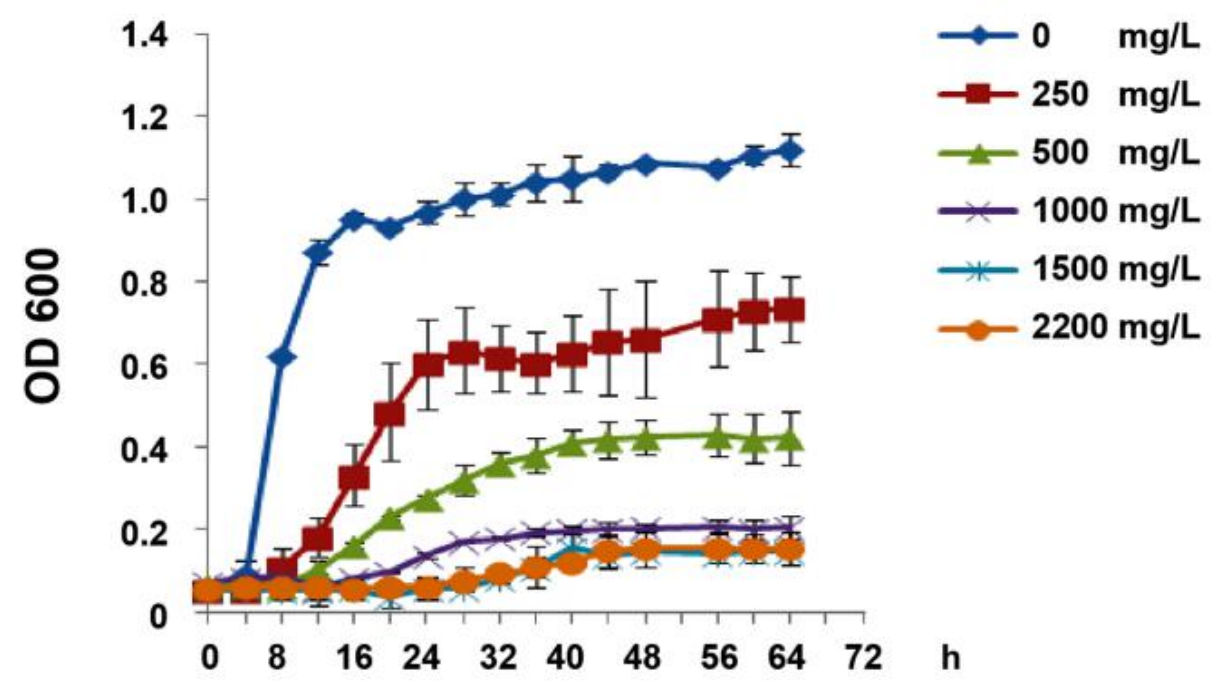

Fig. 5 The growth curves of strain ST7 at different concentrations of manganese stress.

\section{Analysis of transcriptome data}

To investigate the response on the manganese stress of strain ST7, we constructed eight CDNA libraries at stage 1 and stage2. The levels of gene expression were screened for the whole transcriptome under manganese stress by using Illumina Hiseq X-ten platform to sequence the libraries. All of the cDNA libraries generated 106.7 million of clean reads with each read in PE150 base-pair (bp) after quality control and filtering. All samples showed similar matching percentages, with $80.67 \%$ on average of reads mapping onto the reference genome of $B$. safensis and the Q30 above $89.34 \%$ (Table 1). The results showed that eight libraries presented high quality, and obtained high coverage of the $B$. safensis reference genome. It allowed us to compare the expression patterns from strain ST7 between groups with and without manganese stress treatment. 
Table 1 The statistical statement of transcriptome sequencing of $B$. safensis strain ST7

\begin{tabular}{ccccccc}
\hline Samples & $\begin{array}{c}\text { Clean } \\
\text { data } \\
\text { (bp) }\end{array}$ & $\begin{array}{c}\text { Obtained } \\
\text { reads }\end{array}$ & $\begin{array}{c}\text { Mapped } \\
\text { reads }\end{array}$ & $\begin{array}{c}\text { Mapping } \\
\text { ratio (\%) }\end{array}$ & Q30 (\%) & GC (\%) \\
\hline L01 & 3.66 & 12343385 & 10940366 & $88.6 \%$ & 89.37 & 43.17 \\
L02 & 5.29 & 17844906 & 15975336 & $89.5 \%$ & 89.34 & 43.45 \\
L03 & 2.88 & 9787928 & 8611058 & $88.0 \%$ & 89.64 & 43.40 \\
L04 & 4.37 & 14746281 & 13015444 & $88.3 \%$ & 89.76 & 43.05 \\
L05 & 3.98 & 13898878 & 9666959 & $70.0 \%$ & 94.51 & 48.22 \\
L06 & 3.78 & 13087400 & 10499441 & $80.2 \%$ & 94.00 & 43.70 \\
L07 & 3.61 & 12635044 & 8635796 & $68.3 \%$ & 94.30 & 45.87 \\
L08 & 3.55 & 12393004 & 8985159 & $72.5 \%$ & 94.22 & 45.56 \\
\hline
\end{tabular}

\section{Differential expressed genes numbers between two growth stages}

After mapping to the $B$. safensis genome, we obtained 3574 genes from the eight libraries, occupied $87.4 \%$ of the reference total gene number (3574/4088). Of those, large number of genes expressed at very low level. Based on criteria of CPM larger than 200 and FDR less than $0.10,1199$ genes from total 3570 genes dataset at stage1 (Table S1) were selected as expressed genes with high quality, while it was 1462 genes from total 3152 genes at stage 2.

We used two softwares of EdgeR and DESeq2 to analyze the differently expressed genes (DEGs). At stage1, 1040 genes differently expressed between two groups after join results from both softwares with the threshold of $|\log F C| \geq 1$, in which, 502 genes were increased and 538 genes were decreased in the $\mathrm{Mn}(\mathrm{II})$ dealt group (Fig. 6A). The range of log2FC values of DEGs was varied from -3.79 to 6.03 . For stage 2, all of the 1462 quality expressed genes were transcribed differently with log2FC from -13.77 to 8.49, in which 760 genes were up-regulated and 702 genes were down-regulated in the $\mathrm{Mn}$ (II) dealt group compared with its control (Fig. 6B). And 575 DEGs were shared between two stages with 624 genes specific at stage 1 while 887 genes expressed only at stage2 (Fig. 7). 

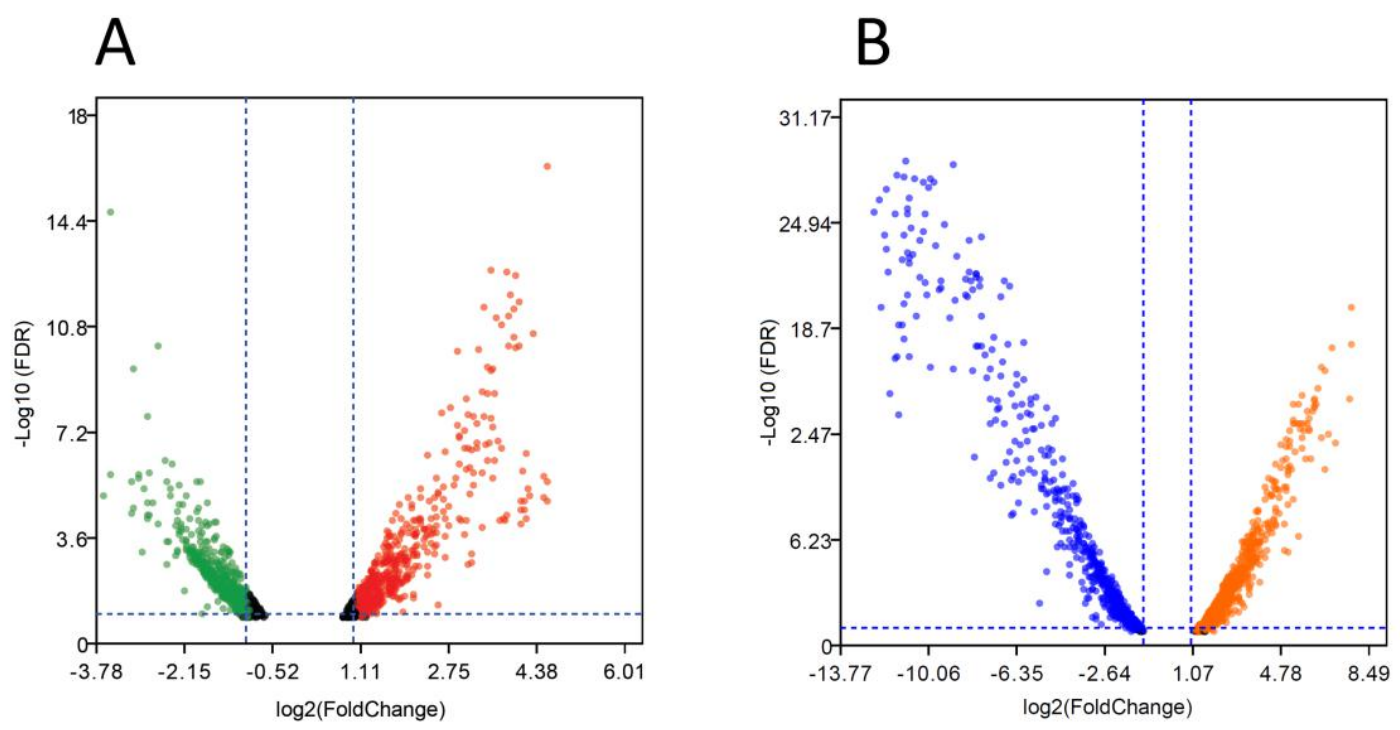

Fig. 6 The different expressed genes of strain ST7.

A: DEGs in first stage of the mid-exponential phase. B: DEGs in second stage of the onset of stationary growth phase. The green and blue dots denoted as the down-regulated genes while the red and orange dots as the up-regulated genes.

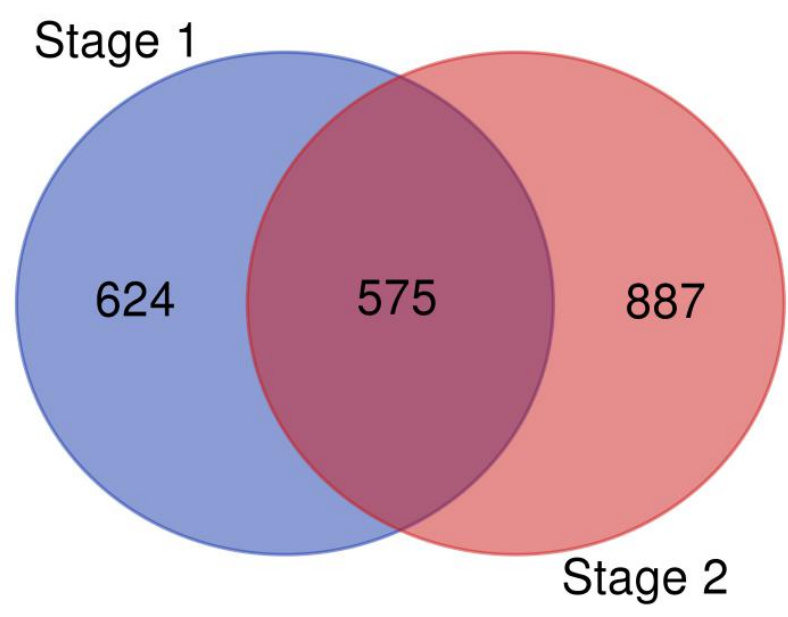

Fig. 7 The high-quality expressed genes between two stages.

\section{Candidates of response genes under manganese stress}

To find out the response genes under manganese stress, the high expressed DEGs were screened out according to the criteria of CPM larger than 10000 and Log2FC larger than 4. Only nine genes were qualified and all of them were up-regulated in manganese dealt group at stage1 (Table S2). Of those, three genes matched KO terms, in which gene1073 was in the lysine degradation pathway, gene3829 was in the porphyrin and chlorophyll metabolism pathway, and gene1591 occupied two pathways, which 
were the two-component system pathway and bacterial chemotaxis pathway (Table 2).

For stage2 of strain ST7, total of 131 genes were high expressed in $\mathrm{Mn}(\mathrm{II})$ dealt group with 88 genes down-regulated and 43 genes up-regulated (Table S3). Of these, 78 genes were enriched in metabolism pathways including 32 up-regulated genes and 46 down-regulated genes (Table S3). For the 32 up-regulated genes, nine of them enriched in material metabolism paths including amino acid metabolism, carbohydrate metabolis, and metabolism of cofactors and vitamins. The dihydrolipoyl dehydrogenase, coded by gene2371, participated nine metabolism paths, including citrate cycle, lysine degradation, tryptophan metabolism pathways etc. It was worthy to notice that fifteen genes gathered in transporter. It indicated that the transport process was much active, which was stimulated by $\mathrm{Mn}$ (II) at stage2. For the 46 down-regulated genes, most of them clustered in metabolism including carbohydrate, energy, amino acid, terpenoids and polyketides and other secondary metabolites biosynthesis. The cell growth including spore were affected by nineteen genes. Nearly half numbers of down-regulated genes inhibited the bacteria spore growth.

Furthermore, the expression pattern under $\mathrm{Mn}(\mathrm{II})$ stress was compared between the two stages (Table S4, Fig. 8). Total of 140 genes were great varied between two stages. The expressed level of 51 genes in stage 2 increased ten times than that at stage1. Of these, total of twenty-six genes enriched in carbohydrate, energy, lipid, amino acid, cofactors and vitamins metabolism pathways. Some of them took part in more than one pathways including nine genes, gene89, gene363, gene2844, gene2371, gene2070, gene2036, gene2035, gene201 and gene1923. And eleven genes gathered in transporter pathways were up-regulated including gene425. There found 89 genes decreased about ten times in the stationary phase, including two genes, gene3709 and gene3346, specific expressed in the mid-exponential phase. Total of 24 genes enriched in the cell growth pathways, and seven genes were down-regulated in three pathways or brite hierachy, which were ribosome, peptidases and inhibitors, oxidative phosphorylation (Table S5). 


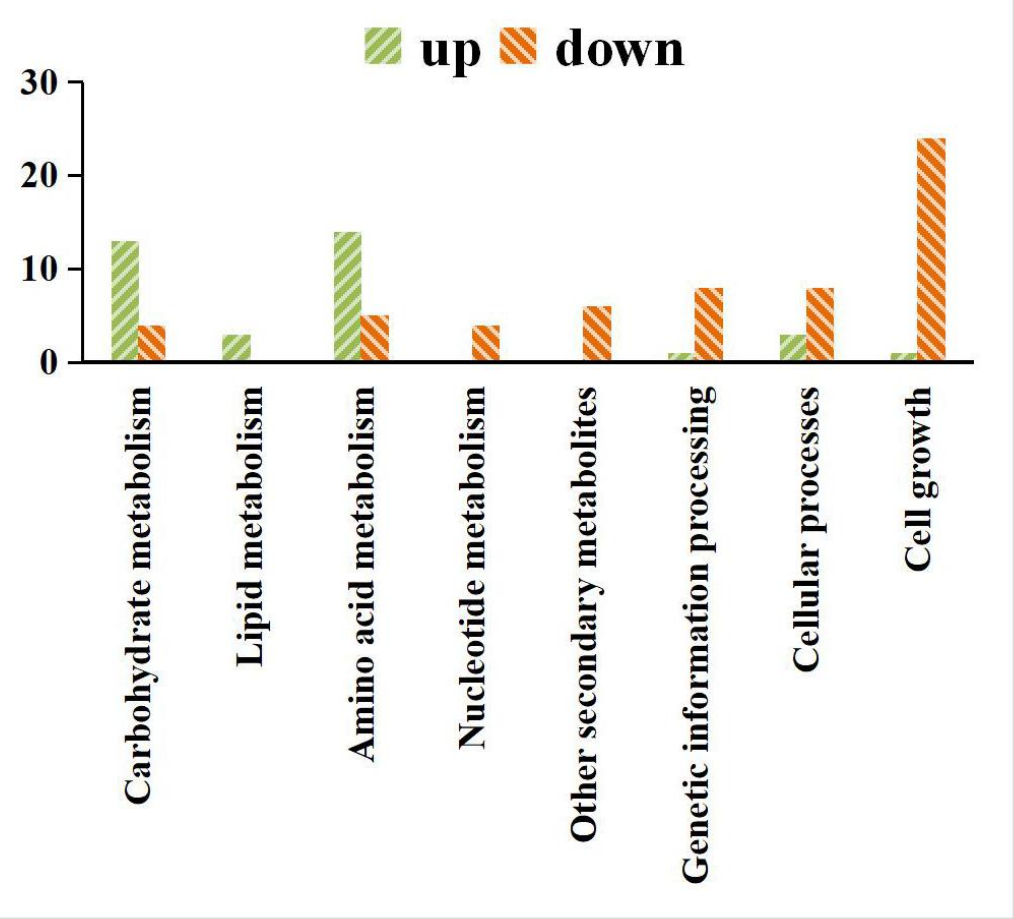

Fig. 8 The variable gene numbers based on KEGG enrichment hierarchy at stage 2 compared with that of stage 1.

For the whole 140 variety genes between two stages, more than $37 \%$ of non redundant genes (52/140) were classified into metabolism category (A09100) (Table S5). Compared with stage1 of strain ST7, most of genes related with carbohydrate metabolism (B09107 and B09101) together with amino acid metabolism were increased at stage 2, but genes participated nucleotide metabolism (B09104) and secondary metabolites (B09109 and B09110) were decreased. In the process of genetic information processing, six genes coded for 50 S ribosomal protein L6, L10, L14, L16, L18 together with 30 S ribosomal protein S5 and S8 in the ribosome assembly were down-regulated. In the cellular processes (A09140), biofilm formation related two genes (B09145), gene3036 and gene3564 coded for S-ribosylhomocysteine lyase and glycosyltransferase, were increased while four flagellar genes related with cell motility (B09142) and Bacterial chemotaxis (C02030) decreased. Interestingly, we found 33 genes related with flagellum which were up-regulated in the first stage, while only eleven of them expressed at stage 2 with 8 of 11 down-regulated (Table 3). The pathway for these genes enriched in both of flagellar assembly and chemotaxis, and Brite hierarchies of transporters and bacteria motility.

\section{Confirmation of DEGs}


We selected randomly seventeen expressed genes to confirm by using RT-qPCR method. The expression profile of seventeen genes were consistent with the trend detected by transcriptomic abundance changes based on RNA-seq data (Fig. 9).

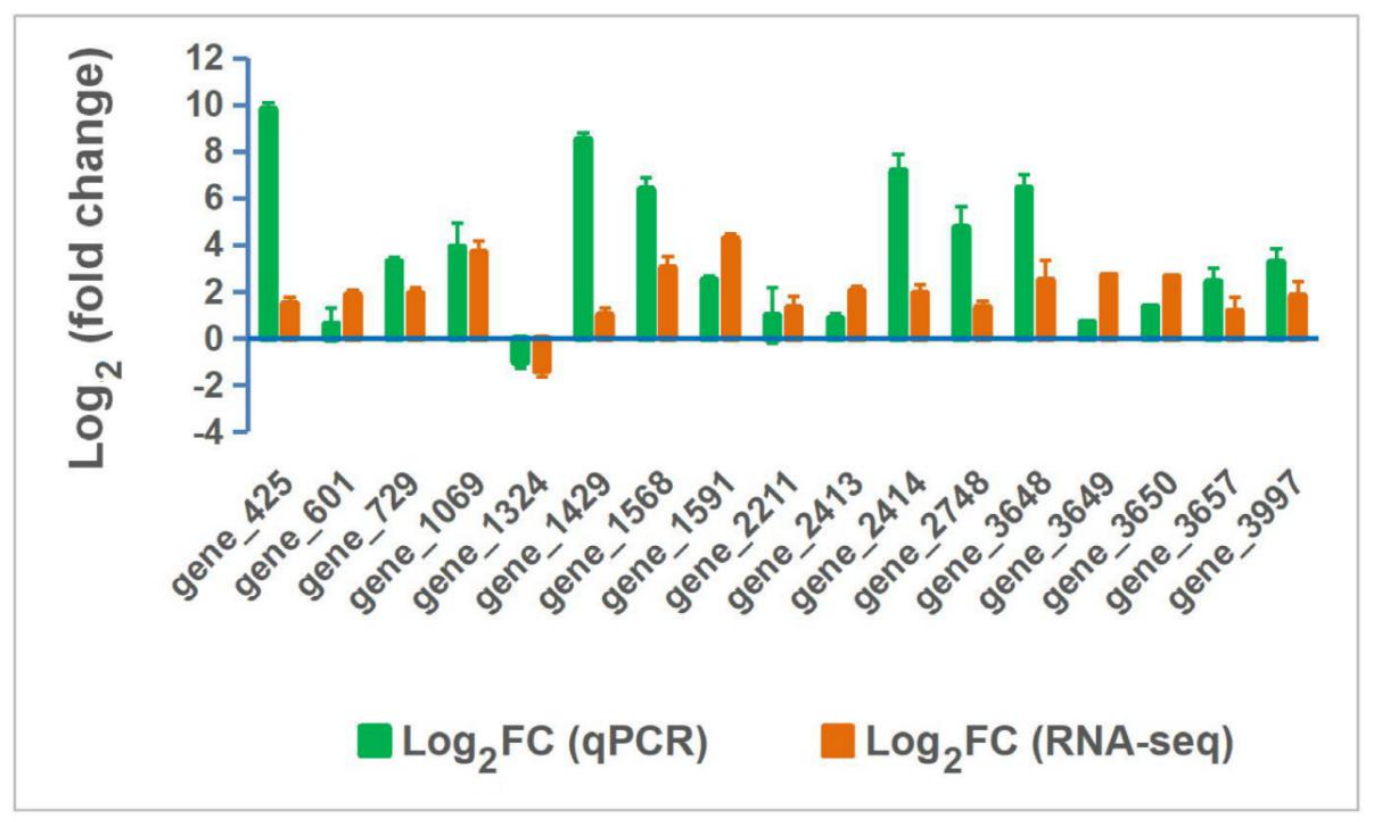

Fig. 9 The pattern of expressed genes confirmed by RT-qPCR method cultured in media supplied with $250 \mathrm{mg} / \mathrm{L} \mathrm{Mn(II)}$.

\section{Function demonstration of gene601}

By homologous recombination technology, the partial fragment of gene601 without stop codon with 696 bp in length was generated as described previously from the genomic DNA of strain ST7 [24]. The partial fragment of gene601 was fused after the complete kanamycin gene by PCR method and then transformed into the wild strain ST7 using electroporation. According to the resistance against kanamycin, the knockout colony mutant $\Delta$ gene601 was selected out. The in-frame deletion of gene601 were verified by PCR amplification and sequencing. Although the blue colour between two bacteria colonies was not obvious cultivated for 16 hours, but the colour was much weak of the mutant $\Delta$ gene601 than that of wild strain ST7 after incubated for seven days under Mn(II) stress (Fig. 10). It demonstrated that the ability of mutant $\Delta$ gene601 was decreased after knockout of gene601. 

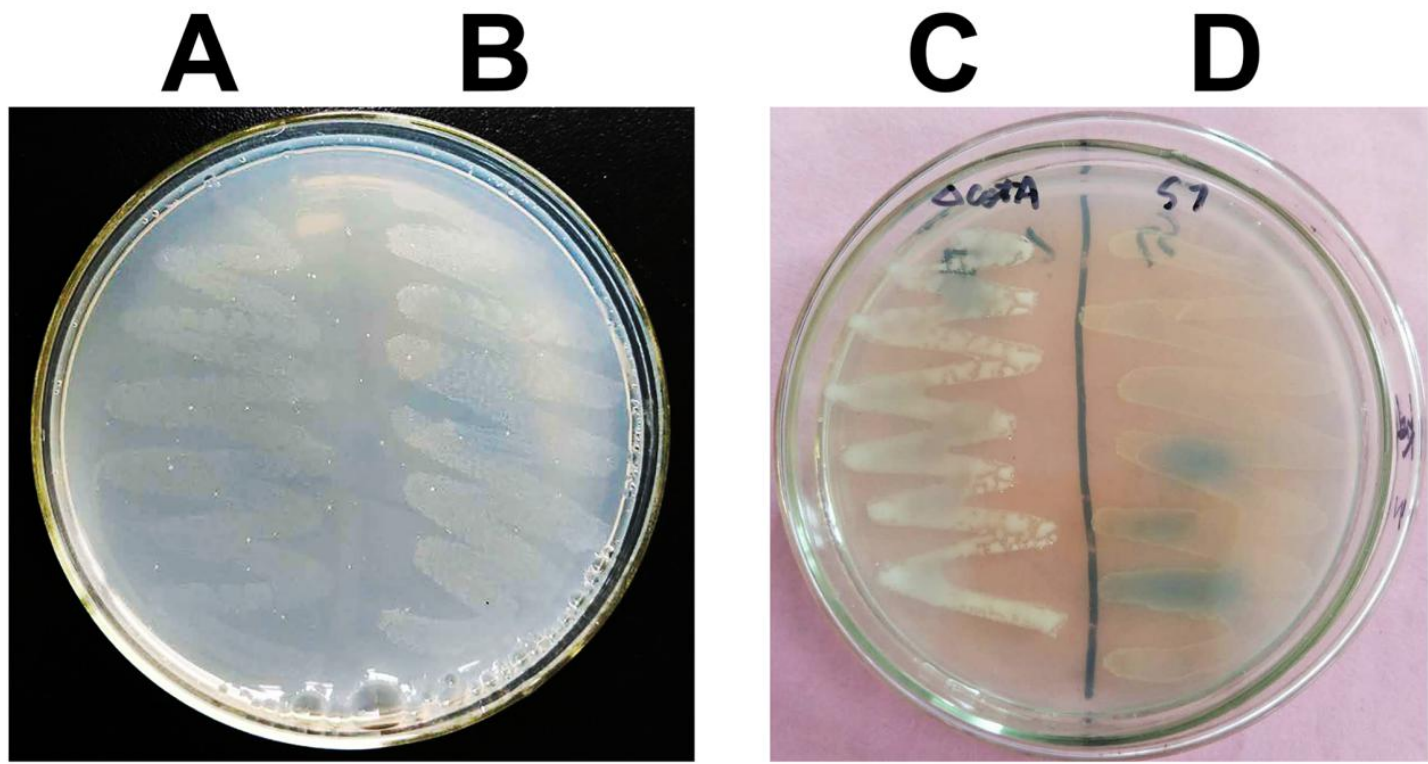

Fig. 10 Determination for the manganese oxidation ability of mutant $\Delta$ gene601.

Both of the mutant $\Delta$ gene601 and wild strain ST7 were cultivated on PYCM media plate with $250 \mathrm{mg} / \mathrm{L}$ Mn(II). A: the mutant $\Delta$ gene601 cultivated for 16 hs. B: wild strain ST7 cultivated for 16 hs. C: the mutant $\Delta$ gene601 cultivated for seven days. D: wild strain ST7 cultivated for seven days.

\section{Discussion}

In the present paper, a strain ST7, was isolated from the surface soil of the Songtao manganese mine, Guizhou province. The isolated strain ST7 could survive on $2200 \mathrm{mg} / \mathrm{L} \mathrm{MnCl} 2$ media, although the growth velocity was very slow (Fig. 5). The manganese oxidation activity of strain ST7 was further demonstrated to oxide $\mathrm{Mn}(\mathrm{II})$ into $\mathrm{Mn}$ (III) or Mn(IV) oxides by LBB quantification with remove capacity of $82 \%$. The ability of strain ST7 was near to Arthrobacter sp. strain HW-16 with oxidation ration of $66.28 \%$ in $3000 \mathrm{mg} / \mathrm{L} \mathrm{Mn(II)} \mathrm{media} \mathrm{[25]} \mathrm{and} \mathrm{much} \mathrm{higher} \mathrm{than} \mathrm{that} \mathrm{of} B$. cereus strain P1 [26] and Streptomyces spinoverrucosus strain NB-7 [27].

Based on the physiological and biochemical properties together with the similarity of 16S rRNA gene sequence, it could not distinguish two close species between Bacillus safensis and Bacillus pumilus because the sequences similarity of $16 \mathrm{~S}$ rRNA gene is more than $98 \%$ (Fig. S2). Previous reports showed that $B$. safensis and B. pumilus, along with other Bacillus, are hard to distinguish from one another if only classify them on the differences of colony morphology, physiological and biochemical detection and 16S rRNA gene similarity [21]. These closely related Bacillus species are sorted to be $B$. pumilus group. Multiple genome comparison is performed among species of $B$. pumilus group which gives a hint that the gyrA gene phylogenetic distances is much similar with that by using whole genome 
phylogenetic analysis methodology on 65 whole genome sequences of Bacillus [22]. Herein, the NJ tree was constructed using the gyrA gene sequences, in which the distance of strain ST7 gyrA gene was much close to that of $B$. safensis than the other Bacillus sp. The strain ST7 was then identified to be $B$. safensis strain ST7.

It is reported that the time point to precipitate $\mathrm{Mn}(\mathrm{III}, \mathrm{IV})$ from $\mathrm{Mn}(\mathrm{II})$ on the cell surface is upon reaching stationary phase in both of two strains, Pseudomonas putida MnB1 and GB-1. The time to produce a kind of $\mathrm{Mn}(\mathrm{II})$ oxidizing protein is from late logarithmic to early stationary stage [28]. But in Pseudomonas aeruginosa strain PAO1, cultured liquid at logarithmic stage could produce manganese oxidizes [29]. Therefore, we designed to detect the gene expression profiles in both the mid-exponential growth phase and the onset of stationary phase.

\section{The adaptation of strain ST7 under Mn(II) stress at exponential growth phase}

In the mid-exponential growth phase of strain ST7, there found nine high expressed DEGs under Mn(II) stress. Of those, gene1073, encoded lysine 6-monooxygenase, also named as lysine N6-hydroxylase (iucD) [EC:1.14.13.59]. The enzyme from Nocardia farcinica catalyzes the hydroxylation of I-Lys in the biosynthetic pathway of the nocobactin, a kind of siderophore [30]. Siderophore is low molecular weight

iron chelator that is secreted by bacteria growing under low iron condition [31]. Recently, lots of previous works demonstrated that manganese could inhibit the uptake of iron and the chelator of iron can combine with $\mathrm{Mn}(\mathrm{III})$ as well [32]. The binding of chelator and $\mathrm{Mn}(\mathrm{III})$ further accelerate the oxidation of $\mathrm{Mn}(\mathrm{II})$ into $\mathrm{Mn}(\mathrm{III})[33,34]$. Moreover, the complexes of $\mathrm{Mn}(\mathrm{III})$ and the siderophore function as superoxide dismutase and help the oxidation of $\mathrm{Mn}(\mathrm{II})[35,36]$. It was interested that both of gene1071 and 1074 , coded for lucA/lucC family siderophore biosynthesis protein were high expressed with 3.72 and 4.47 times higher than the control group. And iucA, iucD and iucC genes coded for three enzymes to participate the biosynthesis of aerobactin, a kind of siderophore, in Escherichia coli [37]. Herein, the $\mathrm{Mn}$ (II) oxidation process in stage1 may rely on siderophore of lucA/lucC family in strain ST7.

The gene3829 coded for iron ABC transporter ATP-binding protein, clustered in heme oxygenase, took part in porphyrin and chlorophyll metabolism. It is reported that some kinds of $A B C$ transporter, such as PsaA protein from Streptococcus pneumoniae, could uptake $\mathrm{Mn}$ (II) and possibly $\mathrm{Zn}$ (II) as well $[38,39]$. In the patient epithelial cells, the high-affinity manganese and zinc transporters of Salmonella are upregulated in the niche with high-degree limitation of metal ions [40]. It might present a similar 
function for the protein coded by gene3829 when the strain ST7 was cultured in iron deficiency PYCM media.

The gene1591 coded for chemotaxis protein CheA and gathered in the bacterial chemotaxis related with cell motility process (Table 2). In alphaproteobacteria Ruegeria sp. TM1040, chemotaxis proteins are upregulated to stimuli motility and escape the high $\mathrm{Mn}$ (II) concentration, in which both of CheW and CheB together with flagellar proteins, FlgL, FlgK, FlgB and FlgG, increased more than five times in 200 uM Mn(II) solution [41]. Furthermore, cheA could excise regulator as a central member of two-component system to sense and transmit the signal of high Mn(II) environment, which then coordinate multiple cellular functions including metabolism, growth and survival of bacteria [42]. Both of chemotaxis and phototaxis are disappear when the central core of che $A$ gene is deleted in Halobacterium salinarium. And the CheA, similar to E. coli, is thought to be the transmitter protein that relays signals from both chemoreceptors and photosensory transducers to the flagellar motor switch [43]. In both of Eubacteria and Archaea, two-component signaling system is much conserve manner to execute response to chemical or light signals. The mechanism of chemotaxis and phototaxis is that a chemo- or phototactic signal causes CheW-mediated selfphosphorylation activity of CheA by ATP, then the phosphorylated CheA provides phosphate to CheY, the phosphorylated CheY stimulates the flagellar motor switch and change the motility and direction of bacterium. In strain ST7, all of thirty-three genes coded for flagella assembly proteins were up-regulated in the group dealt with $250 \mathrm{mg} / \mathrm{L} \mathrm{Mn}$ (II) at the mid-exponential growth phase (Table 3). It was corresponding to the increase motility ability of strain ST7 at Mn(II) stress (Fig. 4).

It was worthy to notify the gene601 of strain ST7, which encoded a copper oxidase, and the product of gene601 is classified as spore coat protein $A(\cot A)$, manganese oxidase [EC:1.16.3.3] by KEGG (K06324). The coded protein of strain ST7 is different from that record of the reference gene deposited in NCBI, with $98 \%$ of similarity (1497/1533) in nucleotides, and 99\% similarity (504/510) in amino acids sequence (Fig. S34). The similarities of cotA between strain ST7 and the other Bacillus cotA enzymes were much high while it fall down rapidly if compared with other proteins outside Bacillus with manganese oxidase capacity confirmed by experiments. It is $95.3 \%(486 / 510)$ identity to the cotA of Bacillus pumilus strain WH4 reported by Su et al [15], 69\% (353/514) identity to the cotA from Bacillus subtilis strain 168 (NP_388511.1) [44]. The length of proteins with Mn(II) oxidation activity in other bacteria are quite diverse from that of Bacillus species [29, 45-48]. However, the four signature domain regions for copper binding could be found out from the cotA of strain ST7 when compared with other 
reported proteins with manganese oxidation ability by using Mega and muscle program (Fig. S3). The multicopper oxidase (MCO) family is composed of distantly related domains to bind with copper ions that are involved in electron transfer during the oxidation of various substrates, like $\mathrm{Fe}$ (II) or $\mathrm{Mn}$ (II) [49]. It includes three members of MCO family: laccase, ascorbate oxidase, and ferroxidase. All of them contained the four domain enriched in histidine residues as the regions from domain 1 to 4 in Figure S3. The putative copper-binding motifs in the cotA of strain ST7 were assigned to range from residues 102 to 110,149 to 154,419 to 426 , and 491 to 502 , with highly conserved of ten histidine occupied $42.9 \%$ of 35 residues in Fig. S3. It indicated that the gene601 of strain ST7 might involve in producing a protein to oxidize the soluble manganese compound just like the other members of multicopper oxidase family. In the group with $\mathrm{Mn}(\mathrm{II})$, the expression level of gene601 is 3.66 times higher than that in control group at stage1 (Table S1). It indicated that the protein cotA of strain ST7 could oxidize $\mathrm{Mn}$ (II) at the first stage, and the knockout of gene601 did reduce the Mn oxidation capacity (Fig. 10).

In brief, the great change at stage 1 might focus on uptake of $\mathrm{Mn}$ (II) by increasing of siderophores, and cheA protein to elevate the chemotaxis and motility of bacteria, and the main enzyme to oxidize $\mathrm{Mn}(\mathrm{II})$ was relied on cotA coded by gene601.

\section{The response of strain ST7 at stationary phase under Mn(II) stress}

Of those high expressed genes at stationary phase (Table S3, Table S5), thirty-two genes were up-regulated. Most of them were in the process of catabolism of large molecules such as glycolysis, citrate cycle, many kinds of amino acids degradation, peptidases etc. However, a cluster of fifteen gene functioned as transporters were increased in the group dealt with $\mathrm{Mn}(\mathrm{II})$. It was noted that two clusters of genes were high expressed. The first cluster was gene3340, gene3341, gene3342, gene3343, gene3344. The second one included gene3830, gene3831, gene3833, gene3834, gene3835. They might express in common as operons. The fifteen genes were annotated to be nine kinds of transporter proteins, which were $A B C$ transporter substrate-binding protein, $A B C$ transporter ATP-binding protein, iron-uptake system-binding protein, , iron $A B C$ transporter permease, iron(3+)-hydroxamate-binding protein fhuD, heme ABC transporter substrate-binding protein IsdE, PTS galactitol transporter subunit IIC, amino acid permease, and copper-binding protein. The ABC transporters are widely distributed membrane proteins and import/export molecules across the membrane from bacteria to human cell [50]. Type I transporters import sugars and amino acids metabolites, and the second type of transporters uptake complexes of organic compound and metal, including vitamin B12, iron-siderophores, and heme. 
All $A B C$ transporters are basically consisted of two domains, the first one is two NBDs (intracellular nucleotide-binding domain), and the second one is two TMDs (trans-membrane domain). ATP binds with the NBD domain and provides energy by ATP, and the TMDs domains provide a path for the cargo to go through the cell membrane. Additionally, ABC transporter needs a SBP, substrate-binding protein, to carry the substrate outside the membrane reaching to the TMD domain of ABC transporters [51]. Of the nine annotated proteins, two of them classified to be $A B C$ transporters in cell membrane, included $A B C$ transporter ATP-binding protein and iron ABC transporter permease. And four of them were SBPs to help $A B C$ transporter to uptake iron and other metal ions, which were $A B C$ transporter substrate-binding protein, iron(3+)-hydroxamate-binding protein fhuD, iron-uptake system-binding protein, heme $A B C$ transporter substrate-binding protein IsdE. The mechanism of PTS transporter is based on group translocation, much different from both of ABC-type and NRAMP transporters. The phosphoenolpyruvate-dependent carbohydrate transport system (PTS) performs the translocation together with concomitant phosphorylation of sugars, galactitol and hexitols [52]. The amino acid permease mainly uptake amino acids into the cell and some of them are ABC-type transports [53]. The copper-binding protein, coded by gene425, is the carrier to bind with $\mathrm{Cu}(\mathrm{I})$. It is demonstrated that the copper-binding protein, $\mathrm{CopL}$, is lipoprotein on cell surface, which holds four $\mathrm{Cu}(\mathrm{I})$ on the outer surface of the cell and contributes to the Cu effluxer effects of proteins CopA or CopB [54]. It has been reported that one of copper-binding protein, prion protein (PrP), could bind with both of copper and manganese [55]. It suggested that these transporters including copper-binding protein coded by gene425 might contribute to extrude $\mathrm{Mn}(\mathrm{II})$ from bacterium.

In Bacillus subtilis, there reported two specific transform systems of $\mathrm{Mn}(\mathrm{II}), \mathrm{mnt} A B C D$ and $\mathrm{mntH}$. The mntABCD operon encodes a four ABC transporters of Mn binding lipoprotein, ATP-binding protein and two permeases. MntH codes for the proton-coupled manganese transporter. The mntABCD system drives by energy from ATP hydrolysis, while the mntH protein belongs to the family of NRAMP and uses the $\mathrm{H}+$ electrochemical gradient between two sides of the cell membrane. Both of them are regulated by mntR. On the other hand, the manganese efflux pump, coded by mntP gene, is responsible for transport excess manganese out of cell. Two transportes systems of MntH and MntABCD could be inhibited by $\mathrm{Mn}(\mathrm{II})$ on the presence of regulator MntR. At high concentration of Mn(II) media, MntR repress the transcription of $m n t H$, while it increase the activity of $m n t A B C D$ operon at low concentration of $\mathrm{Mn}(\mathrm{II})$ solution [56]. However, the annotation of reference genome in Bacillus safensis (Assembly no. GCF_001895885.1) is imperfect, in which there does not contain the annotation of mntABCD, mntH and 
mntP except for mntR coded by gene2410. We herein realigned the clean data from eight libraries taking the Bacillus subtilis as reference with assembly no. of GCF_000009045.1. Then, four genes, the $m n t B$, $m n t D, m n t H$ and $m n t P$, were annotated to be gene3359, gene3360, gene474, gene3661 in the strain ST7, the other mnt genes were not found out. However, all of four genes decreased obviously except for gene2410 coded for mntR, which was increased with log2FC of 2.17 times in stage2. It suggest that both of $m n t A B C D$ and $m n t H$ might not functioned in the transport of $\mathrm{Mn}$ in B. safensis strain ST7.

A total of nineteen genes were decreased and clustered into the cell growth path with sporulation. Of those, four genes were hypothetical proteins, and eleven genes coded for protein of spore assembly in the sporogenesis process. The other four genes coded four enzymes related with sporogenesis. Both of gene1627 and 1628 coded for dipicolinic acid synthetase subunits A and B take part in synthesis of dipicolinic acid (DPA) during sporulation period in the mother cell $[57,58]$. The gene2117 coded for glycosyltransferase family 2 protein, which catalyzes the transference and modification of monosaccharide in the crust during late stage of sporulation [59]. And gene3170 coded for KapD, which inhibit the spore formation in Bacillus thuringiensis [60]. Nearly half numbers of down-regulated genes blocked the spore growth of bacteria.

\section{The great changeable genes between two stages}

The greatest variant 140 genes between two stages related with types of biological process were sorted out, such as metabolism, cellular process and genetic information processes etc (Table S5). Of those, two genes, gene1568 and gene1579 were worthy notified which coded for the M-ring protein FliF in flagellum basal body and FliM as motor switch of flagellum. The expression patterns of other flagellar related genes were listed in Table 3. Interestingly, we found 33 genes related with flagellum which were up-regulated in stage 1, while only eleven flagellum genes expressed and 9 of 11 were down-regulated in the stage 2 of strain ST7. Flagellar structure is much complex contained three basic structures, the hook, basal body, together with long filament [61]. The basal body stretch into the bacteria envelope, governs its internal apparatus of secretion to output the other proteins, and gives the point for flagella to rotate by stator ptoton channel. The hook connects to the basal body and alters the rotation angle by FliG as rotor and FliM and FliY to control the direction. The filament, consisted of one kind of flagellin protein, is a long helical line as the propeller of flagella motion. Of those 33 up-regulated genes, all of structure proteins expressed in a high level, which contained in the assemble of flagella emerge, such as FlaD and flagellar capping protein used in hook, motA and motB in the stator, FliD, FlgK and FlgL in the 
filament, FlgB, FlgC, FliE, FliF for the basal body, and FliG for the rotor, FliM and FliY to control the direction. However, most of them did not detected out or down-regulated from the whole transcriptome sequencing at stage2 except for two flagellin genes, gene1178 and gene1206. It is reported that Bacillus subtilis divided into two states, including cell chains joined by end-to-end and single bacterium moving alone during exponential growth of bacteria [61]. And the flagellar genes of $B$. subtilis are expressed in exponential growth phase, but the sessile biofilm-forming related genes are induced in the stationary phase in which the transition from motile cells to sessile growth is controlled by phosphorylation of modulator DegU [62], but the homology of DegU (coded by gene3536) does not detected out from the transcriptome data at the onset of stationary phase of strain ST7. Mn(II) exposure does increase the flagellar gene expression and gut bacteria motility in male mice, such as Flil, sigma factor for flagellar operon [63]. It was coincided with the increased motility of strain ST7 at Mn(II) stress (Fig. 4).

Compared with stage 1 , the main variation in stage 2 was focused on those decreased genes for spore formation and flagella assembly together with the increased genes for transporters to extrude manganese outside of the bacteria.

\section{Conclusions}

The gene coded for siderophores were strong transcribed to uptake $\mathrm{Mn}$ (II) as cofactor to enzyme and the gene601 coded for cotA to oxide the excessive $\mathrm{Mn}(\mathrm{II})$ as the bacteria grew very fast at the mid-exponential growth phase (stage1). When entering into the stationary phase (stage2), genes related with spore formation and flagella assembly were great down-regulated while the transporter genes were increased to extrude too much $\mathrm{Mn}$ (II) outside of bacteria to avoid the harmness of $\mathrm{Mn}$ (II) as the slowing down of bacteria growth.

\section{Methods}

\section{Isolation and training of MOB strain}

Samples were collected from 0 to $20 \mathrm{~cm}$ depth of the subsoil located in Songtao manganese mine (E108 $\left.51^{\prime} 50^{\prime \prime}, N^{\circ} 7^{\circ} 58^{\prime} 30^{\prime \prime}\right)$, Guizhou province, China. The soil samples were suspended in sterile water at the ratio of $1: 9$ and the mixture was vortexed vigorously for $10 \mathrm{~min}$. About $80 \mu \mathrm{L}$ supernatant fluid was plated on PYCM solid medium (Peptone $0.8 \mathrm{~g} / \mathrm{L}$, yeast extract $0.2 \mathrm{~g} / \mathrm{L}, \mathrm{K}_{2} \mathrm{HPO}_{4} 0.1 \mathrm{~g} / \mathrm{L}, \mathrm{MgSO}_{4} \cdot 7 \mathrm{H}_{2} \mathrm{O} 0.2$ $\mathrm{g} / \mathrm{L}, \mathrm{NaNO}_{3} 0.2 \mathrm{~g} / \mathrm{L}, \mathrm{CaCl}_{2} 0.1 \mathrm{~g} / \mathrm{L},\left(\mathrm{NH}_{4}\right)_{2} \mathrm{CO}_{3} 0.1 \mathrm{~g} / \mathrm{L}, 1.5 \%$ agar, $\left.\mathrm{pH} 7.0\right)$ with $200 \mathrm{mg} / \mathrm{L} \mathrm{MnCl}_{2}$ filtered with $0.22 \mu \mathrm{m}$ filter, and incubated at $28^{\circ} \mathrm{C}$. The single colony was trained by plating on the solid PYCM 
media with different concentration gradients of $\mathrm{MnCl}_{2}$ from 700 up to $2200 \mathrm{mg} / \mathrm{L}$. The highly tolerant strain ST7 was obtained.

\section{Detection of Mn removal efficiency}

The bacteria suspensions of strain ST7 at exponential growth phase were transformed into PYCM with $250 \mathrm{mg} / \mathrm{L} \mathrm{MnCl} 2$ on a scale of $1: 20$, and cultured at oscillation of $180 \mathrm{rpm}$ at $28^{\circ} \mathrm{C}$. Aliquots supernatant were collect after seven days and detected the rest $\mathrm{Mn}$ (II) content in medium by using atomic absorption spectrophotometry in triplicates.

The Mn removal efficiency (RE) was calculated by equation:

$$
\operatorname{RE}(\%)=\left[\left(\mathrm{C}_{0}-\mathrm{C}_{\mathrm{S}}\right) / \mathrm{C}_{0}\right] \times 100
$$

where $\mathrm{C}_{\mathrm{s}}$ is the concentration of rest $\mathrm{MnCl}_{2}$ in the supernatant after a certain period of cultivation and $\mathrm{C}_{0}$ is the concentration of $\mathrm{MnCl}_{2}$ at the beginning [64].

\section{Determination of the motility of strain ST7 under Mn(II) stress}

Strain ST7 was punctured into soft-agar medium tube of PYCM containing $0.3 \%$ agar to observe the bacteria motility capacity. The equivalent amount of strain ST7 from exponential growth phase was further placed on PYCM soft-agar plates supplied with or without $250 \mathrm{mg} / \mathrm{L} \mathrm{Mn(II)}$ and incubated for seven days. The diameter of spread colony was measured with ruler.

\section{Identification of isolated strains}

The biochemical characterization and Gram staining were carried out by regular process. Total genomic DNA was extracted by TIANamp Bacteria DNA Kit (TIANGEN) based on the kit protocol. Fragments of gene (16S rRNA and gyrA) were amplified by PCR method using the bacteria genomic DNA as templates [65]. The products of amplification after purification were sequenced directly from two ends of strand by Sanger sequencing method. The consensus phylogenetic tree were constructed by UPGMA method using MEGA7 program [20]. The phylogenetic trees were constructed by bootstrap method after 1000 repetitions.

\section{Mn(II) oxidation activity assays}

Quantitative and qualitative analysis methods were used to test the activity of manganese oxidation of strain ST7 as previous reports $[15,61]$. In brief, taking Staphyloccocus aureus Rosenbach as control, 
bacteria ST7 cultures were spread and cultivated for seven days on agar solid PYCM plates. The colonies on plates or liquid cultures were monitored by the colorimetric dye solution of leucoberbelin blue (LBB) $(0.04 \% \mathrm{w} / \mathrm{v})$ to detect the $\mathrm{Mn}$ oxides products including $\mathrm{Mn}(\mathrm{III})$ and $\mathrm{Mn}(\mathrm{IV})[18,19]$. The manganese oxidation activity of strain ST7 was determined quantitatively by using LBB taking $\mathrm{KMnO}_{4}$ solution for standard curve as previously described $[15,66]$.

\section{Visualization of $\mathrm{Mn}(\mathrm{II})$ oxides by scanning electron microscopy}

The bacteria pellets were prepared for observation by using scan electron microscopy (SEM) as previous report [67]. The strain ST7 pellets cultured for seven days with $2200 \mathrm{mg} / \mathrm{L} \mathrm{MnCl} 2$ or not were collected by centrifugation and were washed in PBS $(\mathrm{pH} 7.4)$ solution. The pellets surface morphology were observed in a Hitachi S-3400N scan electron microscope with 20,000 V accelerating voltage.

\section{Analysis of transcriptome profile of strain ST7 under manganese stress}

\section{Determination of the proper concentration of $\mathrm{Mn}$ (II) stress}

Strain ST7 was cultured in the PYCM liquid medium with sterile $\mathrm{MnCl}_{2}$ at concentration of $0,250,500$, $1000,1500,2000 \mathrm{mg} / \mathrm{L}$, and determined the optical density at $600 \mathrm{~nm}\left(\mathrm{OD}_{600}\right)$ of bacterial suspensions at each time-point from 0 to $64 \mathrm{~h}$ to obtain growth curve. The growth rate of bacteria ST7 at $250 \mathrm{mg} / \mathrm{L}$ $\mathrm{MgCl}_{2}$ dropped by half compared with that of control group. Thus, the $250 \mathrm{mg} / \mathrm{L} \mathrm{of} \mathrm{MgCl}_{2}$ was taken as half-effective dose $\left(E D_{50}\right)$ and used for the manganese stress treatment for transcriptome sequencing by RNA-seq method.

\section{Analysis of transcripts expression profile}

The strain ST7 was incubated in PYCM liquid medium supplemented with $250 \mathrm{mg} / \mathrm{L} \mathrm{MnCl} 2$ as $\mathrm{Mn}$ dealt group, and taking equivalent aliquot of cultures as control group in medium without $\mathrm{Mn}$ (II). Two samples were taken out from each group at the mid-exponential growth phase (stage1) or onset of stationary phase (stage2), respectively. Samples L01 and L02 were prepared from the control group without Mn(II) at stage 1 cultivated for $8 \mathrm{hs}\left(\mathrm{cfu} / \mathrm{mL}=3.183 \times 10^{8}\right)$, and L03 and L04 from the Mn dealt group at stage 1 for $16 \mathrm{hs}\left(\mathrm{cfu} / \mathrm{mL}=3.182 \times 10^{8}\right)$. For stage 2, both of L05 and L06 were sampled from control group in 12 hs $\left(\mathrm{cfu} / \mathrm{mL}=4.635 \times 10^{8}\right)$ while L07 and L08 were from the dealt group in $24 \mathrm{hs}\left(\mathrm{cfu} / \mathrm{mL}=4.573 \times 10^{8}\right.$ ). Pellets from eight samples were washed two times by PBS solution $(\mathrm{pH} 7.0)$ at centrifugation of $10,000 \mathrm{~g}$ $\times 5 \mathrm{~min}$ at $4^{\circ} \mathrm{C}$. Based on the protocol of Genedenovo Biotechnology Co., Ltd (Guangzhou, China), 
cDNA library was constructed. In brief, total RNA of bacteria was prepared by using TRIzol method (Life Technologies, CA, USA) followed by chloroform extraction. The total RNA was digested by RQ1 DNase (Promega, Madison, $\mathrm{WI}$ ) to clear genomic DNA contamination, and purified by phenol and chloroform extraction and anhydrous alcohol precipitation. The RNA quality was detected by NanoPhotometer® spectrophotometer (IMPLEN, CA, USA) and the RNA integrity (RIN) was measured to be from 8.1 to 9.9 using Agilent Bioanalyzer 2100 system (Agilent, Santa Clara, CA). Based on method for IncRNA library, the rRNA was removed from total RNA using the Ribo-Zero Magnetic Gold Kit (Epicentre Biotechnologies, Madison, WI, USA). The library was constructed using the kit of TruSeq RNA Sample Prep (Illumina, USA). The RNA was randomly broken into 200 nt by the kit of Elute Prime Fragment Mix. The first strand of cDNA was produced by the First Strand Master Mix and Super Script II kit (Invitrogen, Carlsbad, CA, USA) to perform the reverse transcription reaction. Using Agencourt RNAClean XP Beads (Beckman Coulter, CA, USA) to purify the cDNA, the second strand was generated by using dNTP mixes with dUTP instead of dTTP. After purified fragmented cDNA was repaired into blunt ends, the fragments were added the poly (A) tail and ligated the adapters. The second strand of CDNA was decomposed using the enzyme Uracil-N-Glycosylase. After amplification by PCR Primer Cocktail, the cDNA fragments were enriched and purified by using the AMPureXP Beads. Then, high-through sequencing was carried out with pair-end of 150 base reads taking the platform of Illumina HiSeq ${ }^{\text {TM }} 2500$.

\section{Analysis for different expression genes}

Raw data were filtered to remove low-quality reads if it contained larger than $10 \%$ unidentified nucleotides $(\mathrm{N})$, larger than $50 \%$ bases containing the phred quality score less than twenty or only barcode adapter using NGSQC Toolkit (http://www.nipgr.ac.in/ngsqctoolkit.html). The reads were then aligned with the reference genome of Bacillus safensis strain KCTC 12796BP (Assembly no.

GCF_001895885.1, containing 4088 genes) using STAR program (version 2.7) (https://github.com/alexdobin/STAR) allowing no mismatches, reads mapped to rRNA were removed. The expression patterns of genes was calculated according to the value of counts per million (CPM) to standardize the gene expression.

$\mathrm{CPM}=10,000,000^{*}(\mathrm{~A} /$ mapped reads $), \mathrm{A}$ is the read counts of one gene.

Both of DESeq2 and edgeR packages on R platform (http://www.r-project.org/) were used to identify deferentially expressed genes (DEGs) across groups. The high quality expressed gene was defined according to the threshold that the CPM value was larger than 200 together with the FDR value $\leq 0.1$. 
The up- or down-regulated genes were recognized if the value of $\mid \log 2$ (fold change)| was more than or equal to one, and was further displayed in the volcano plot taking FDR value and log2FC as coordinate axes by Sangerbox program online (http://sangerbox.com/Tool).

\section{Gene enrichment analysis by KEGG}

The amino acid sequence of DEGs were generated from the assembled transcripts by trinity v2.85 [68].

The amino acid sequences of DEGs were input to analyze the KEGG Orthology by the KEGG Automatic Annotation Server online (KAAS) (https://www.genome.jp/tools/kaas/) taking gene lists from 30 species of Bacillus as references containing 148,323 complete genome sequences.

\section{Validation of DEGs}

The same aliquot total RNA for RNA-seq was used to validate DEG by RT-qPCR method. Specific primers for genes were designed by primer5.0 software (Table S6) taking 16S rRNA as internal reference gene. The qPCR reaction was performed according to previous research $[69,70]$. The corresponding RT-qPCR efficiency (E) was in the range of $90.1-101.9 \%$ (Fig. S4). All assays were performed in triplicates.

\section{Knockout of gene601}

The partial region of gene601 (copper oxidase), were generated as described previously based on homologous recombination technology [24]. In brief, The fragment F1 without stop codon of the target gene was amplified using primers $\cot A-F / \cot A-R$ to get the $5{ }^{\circ}$-terminus fragment about 700 bp (Table S6) from the genomic DNA of strain ST7. The complete kanamycin gene (fragment F2) was obtained from plasmid pPIC9K (Invitrogen life technologies) by PCR method guided by primers km-F/km-R (Table S6). The combined fragment F3 with the fragment F1 (incomplete gene601) at the 5 -end of kanamycin gene (fragment F2), which were fused through the reverse complement sequence between two ends of fragment F1 and F2 by first PCR. Then amounts of F3 was amplificated by second PCR using primers $\operatorname{cotA}-\mathrm{F} / \mathrm{km}-\mathrm{R}$. After digested by BamH I, the fragment F3 formed a circled fragment F4 and was electroporated into bacteria ST7. Based on the resistance against kanamycin, the knockout colonies could be selected out from the solid PYCM media plate supplied with $4 \mu \mathrm{g} / \mathrm{mL}$ kanamycin. Gene601 were deleted through homologous recombination with the fusion structure F4 and verified by PCR amplification and sequencing. The ability of gene knockout strain (mutant $\Delta$ gene601) was assessed by 
$\mathrm{Mn}$ (II) oxidation activity assays using LBB method as previously described, with the wild strain ST7 as control.

\section{Acknowledgements}

The authors are grateful to the leaders for the permission to take soil samples from the Songtao manganese mine, Guizhou province, China.

\section{Authors' contributions}

$\mathrm{XR}$ and JW designed and wrote the manuscript. HL, QT, LY, SH, XN, and SL analyzed data and performed the experiments. All authors have read and approved the manuscript.

\section{Funding}

This work is funded by the Guizhou Province "Hundred" Innovative Talents Project [2016-4012], the National Natural Science Foundation of China (31672390, 31960641), the Guizhou Agriculture Research program (QKHZC[2017]2585, QKHZC[2017]2587, QKHNY[2013]3073), the National High Technology Research and Development Program of China (863 Program) [2013AA102503], the Guizhou Province Science and Technology Innovation Team Building Special (QKHPTRC[2019]5615), The funders monitored the ethics of experiments and provided instruments and financial funds for all of research in the manuscript.

\section{Availability of data and materials}

The sequence data of $16 \mathrm{~S}$ rDNA and gyrase subunit A (gyrA) gene of strain ST7 are available in the NCBI under accession number MT378374 and MT449449.

\section{Ethics approval and consent to participate}

Not applicable.

\section{Consent for publication}

Not applicable.

\section{Competing interests}

All authors declare without competing interests. 


\section{Author details}

${ }^{1}$ College of Animal Science, Institute of Agro-Bioengineering, Guizhou University, Guiyang 550025, China

\section{References}

1. Law N, Caudle M, Pecoraro V. Manganese redox enzymes and model systems: properties, structures, and reactivity. Adv Inorg Chem. 1998;46:305-440.

2. Gao T, Ding M, Yang CH, Fan H, Chai Y, Li Y. The phosphotransferase system gene ptsH plays an important role in MnSOD production, biofilm formation, swarming motility, and root colonization in Bacillus cereus 905. Res Microbiol. 2019;170(2):86-96.

3. Wang X, Qin X, Hao Z, Luo H, Yao B, Su X. Degradation of four major mycotoxins by eight manganese peroxidases in presence of a dicarboxylic acid. Toxins (Basel). 2019;11(10):566.

4. Hsieh SI, Castruita M, Malasarn D, Urzica E, Erde J, Page MD, et al. The proteome of copper, iron, zinc, and manganese micronutrient deficiency in Chlamydomonas reinhardtii. Mol Cell Proteomics. 2013;12(1):65-86.

5. Gao X, Sandberg M, Quach M, Bodin B, Johansson L, Jansson L. Effects of Mn-DPDP and manganese chloride on hemodynamics and glucose tolerance in anesthetized rats. Acta Radiol. 2014;55(3):328-34.

6. O'Neal SL, Zheng W. Manganese toxicity upon overexposure: a decade in review. Curr Environ Health Rep. 2015;2(3):315-28.

7. Tuschl K, Mills PB, Clayton PT. Manganese and the brain. Int Rev Neurobiol. 2013;110:277-312.

8. Bjørklund G, Hofer T, Nurchi VM, Aaseth J. Iron and other metals in the pathogenesis of Parkinson's disease: Toxic effects and possible detoxification. J Inorg Biochem. 2019;199:110717.

9. Leavens TL, Rao D, Anderson ME, Dorman DC. Evaluating transport of manganese from olfactory mucosa to striatum by pharmacokinetic modeling. Toxicol Sci. 2007;97:265-78.

10. Lucchini RG, Guazzetti S, Zoni S, Donna F, Peter S, Zacco A, et al. Tremor, olfactory and motor changes in Italian adolescents exposed to historical ferromanganese emission. NeuroToxicology. 2012;33:687-96.

11. Piazza A, Ciancio Casalini L, Pacini VA, Sanguinetti G, Ottado J, et al. Environmental bacteria involved in manganese(ii) oxidation and removal from groundwater. Front Microbiol. 2019;10:119.

12. Anderson CR, Johnson HA, Caputo N, Davis RE, Torpey JW, Tebo BM. Mn(II) oxidation is catalyzed by heme peroxidases in 'Aurantimonas manganoxydans' strain SI85-9A1 and Erythrobacter sp strain SD-21. Appl Environ Microbiol 2009;75:4130-8.

13. Andeer PF, Learman DR, Mcilvin M, Dunn JA, Hansel CM. Extracellular haem peroxidases mediate $\mathrm{Mn}$ (II) oxidation in a marine Roseobacter bacterium via superoxide production. Environ Microbiol. 2015;17:3925-36.

14. Katsoyiannis IA, Zouboulis AI. Biological treatment of $\mathrm{Mn}(\mathrm{II})$ and $\mathrm{Fe}(\mathrm{II})$ containing groundwater: kinetic considerations and product characterization. Water Res. 2004;38(7):1922-32.

15. Su J, Bao P, Bai T, Deng L, Wu H, Liu F, et al. CotA, a multicopper oxidase from Bacillus pumilus wh4, exhibits manganese-oxidase activity. PLoS One. 2013;8(4):e60573.

16. Tebo BM, Johnson HA, Mccarthy JK, Templeton AS. Geomicrobiology of manganese(II) oxidation. Trends Microbiol. 2005;13:421-8. 
17. Hanse CM, Learman DR. "Geomicrobiology of Manganese", in Ehrlich's Geomicrobiology, 6th Edn, eds Ehrlich HL, Newman DK, Kappler A. (Boca Raton, FL: CRC Press), 2016;403-33.

18. Krumbein WE, Altmann HJ. A new method for the detection and enumeration of manganese oxidizing and reducing microorganisms. Helgoländer wissenschaftliche Meeresuntersuchungen. 1973;25:347-56.

19. Tebo BM, Clement BG, Dick GJ. "Biotransformations of Manganese" in Manual of Environmental Microbiology, 3rd Edn, eds Hurst C, Crawford R, Garland J, Lipson D, Mills A, Stetzenbach L. (Washington, DC: ASM Press), 2007;1225-35.

20. Kumar S, Stecher G, Tamura K. MEGA7: Molecular evolutionary genetics analysis version 7.0 for bigger datasets. Mol Biol Evol. 2016;33:1870-4.

21. Branquinho R, Meirinhos-Soares L, Carrico JA, Pintado M, Peixe LV. Phylogenetic and clonality analysis of Bacillus pumilus isolates uncovered a highly heterogeneous population of different closely related species and clones. FEMS Microbiol Ecol. 2014;90:689-98.

22. Tirumalai MR, Stepanov VG, Wünsche A, Montazari S, Gonzalez RO, Venkateswaran K, et al. Bacillus safensis FO-36b and Bacillus pumilus SAFR-032: a whole genome comparison of two spacecraft assembly facility isolates. BMC Microbiology. 2018;18:57.

23. Patel S, Gupta RS. A phylogenomic and comparative genomic framework for resolving the polyphyly of the genus Bacillus: Proposal for six new genera of Bacillus species, Peribacillus gen. nov., Cytobacillus gen. nov., Mesobacillus gen. nov., Neobacillus gen. nov., Metabacillus gen. nov. and Alkalihalobacillus gen. nov. Int J Syst Evol Microbiol. 2020;70(1):406-38.

24. Liu H, Liu H, Yang S, Wang R, Wang T. Improved expression and optimization of trehalose synthase by regulation of pglv in Bacillus subtilis. Sci Rep. 2019;9:6585.

25. Wan WJ, Xue ZJ, Zhang ZW, He DL. Manganese oxidation characteristics and oxidation mechanism of a manganese-oxidizing bacterium Arthrobacter Sp. HW-16. Huan Jing Ke Xue. 2017;38(5):2036-43. (In Chinese)

26. Fan X, Wang S, Li C. The isolation and identification of an efficient Fe/Mn oxidizing bacterial strain $P 1$, and the optimization of its oxidizing conditions. Biotechnology Bulletin. 2016;32(4):175-83.

27. Wang Y, He F, You J, Chen K, Xu B, Lin Y. Screening and identification of a manganese resistant strain and its manganese biosorption conditions. Acta Agriculturae Boreali-Occidentalis Sinica. 2013;22(7):193-9.

28. Jung WE, Schweissfurth R. Manganese oxidation by an intracellular protein of a Pseudomonas species. Z Allg Mikrobiol. 1979;19:107-15.

29. Brouwers GJ, de Vrind JPM, Corstjens PLAM, Cornelis P, Baysse CC, de Vrind-de Jong EW. cumA, a gene encoding a multicopper oxidase, is involved in Mn2+ oxidation in Pseudomonas putida GB-1. Appl Environ Microbiol. 1999;65:1762-8.

30. Abdelwahab H, Robinson R, Rodriguez P, Adly C, El-Sohaimy S, Sobrado P. Identification of structural determinants of $\mathrm{NAD}(\mathrm{P}) \mathrm{H}$ selectivity and lysine binding in lysine $\mathrm{N}(6)$-monooxygenase. Arch Biochem Biophys. 2016;6:180-8.

31. Neilands JB. Siderophores. Structure and function of microbial iron transport compounds. J Biol Chem. 1995;270(45):26723-6.

32. Duckworth OW, Bargar JR, Sposito G. Coupled biogeochemical cycling of iron and manganese as mediated by microbial siderophores. Biometals. 2009;22:605-13.

33. Bartlett RJ, James BR. Redox chemistry of soils. Adv Agron. 1993;50:151-209.

34. Geszvain K, Butterfield C, Davis RE, Madison AS, Lee SW, Parker DL, et al. The molecular biogeochemistry of manganese(II) oxidation. Biochem Soc Trans. 2012;40:1244-8.

35. Faulkner KM, Stevens RD, Fridovich I. Characterization of $\mathrm{Mn}(\mathrm{III})$ complexes of linear and cyclic 
desferrioxamine as mimics of superoxide dismutase activity. Arch Biochem Biophys. 1994;310:341-6.

36. Parker DL, Morita T, Mozafarzadeh ML, Verity R, McCarthy JK, Tebo BM. Interrelationships of MnO2 precipitation, siderophore-Mn-(III) complex formation, siderophore degradation, and iron limitation in Mn-(II)-oxidizing bacterial cultures. Geochim Cosmochim Acta. 2007;71:5672-83.

37. Ling J, Pan H, Gao Q, Xiong L, Zhou Y, Zhang D, et al. Aerobactin synthesis genes iucA and iucC contribute to the pathogenicity of avian pathogenic Escherichia coli O2 strain E058. PLoS One. 2013;8(2):e57794.

38. Lawrence MC, Pilling PA, Epa VC, Berry AM, Ogunniyi AD, Paton JC. The crystal structure of pneumococcal surface antigen PsaA reveals a metal-binding site and a novel structure for a putative ABC-type binding protein. Structure. 1998;6:1553-61.

39. Delepelaire P. Bacterial $A B C$ transporters of iron containing compounds. Res Microbiol. 2019;170:345-57.

40. Liu Y, Zhang Q, Hu M, Yu K, Fu J, Zhou F, et al. Proteomic analyses of intracellular salmonella enterica serovar typhimurium reveal extensive bacterial adaptations to infected host epithelial cells. Infect Immun. 2015;83(7):2897-906.

41. Learman DR, Hansel CM. Comparative proteomics of Mn(II)-oxidizing and non-oxidizing Roseobacter clade bacteria reveal an operative manganese transport system but minimal $\mathrm{Mn}(\mathrm{II})$-induced expression of manganese oxidation and antioxidant enzymes. Environ Microbiol Rep. 2014;6(5):501-9.

42. Párraga Solórzano PK, Yao J, Rock CO, Kehl-Fie TE. Disruption of glycolysis by nutritional immunity activates a two-component system that coordinates a metabolic and antihost response by Staphylococcus aureus. mBio. 2019;10(4):e01321-19.

43. Rudolph J, Oesterhelt $D$. Chemotaxis and phototaxis require a CheA histidine kinase in the archaeon Halobacterium salinarium. EMBO J. 1995;14(4):667-73.

44. Hullo M-F, Moszer I, Danchin A, Martin-Verstraete I. CotA of Bacillus subtilis is a copper-dependent laccase. J Bacteriol. 2001;183:5426-30.

45. Corstjens PLAM, de Vrind JPM, Goosen T, de Vrind-de Jong EW. Identification and molecular analysis of the Leptothrix discophora SS-1 mofA gene, a gene putatively encoding a manganese-oxidizing protein with copper domains. Geomicrobiol J. 1997;14:91-108.

46. Ridge JP, Lin M, Larsen El, Fegan M, McEwan AG, Sly LI. A multicopper oxidase is essential for manganese oxidation and laccase-like activity in Pedomicrobium sp. ACM 3067 . Environ Microbiol. 2007;9:944-53.

47. Dick GJ, Torpey JW, Beveridge TJ, Tebo BM. Direct identification of a bacterial manganese(II) oxidase, the multicopper oxidase MnxG, from spores of several different marine Bacillus species. Appl Environ Microbiol. 2008;74:1527-34.

48. Geszvain K, McCarthy JK, Tebo BM. Elimination of manganese(II,III) oxidation in Pseudomonas putida GB-1 by a double knockout of two putative multicopper oxidase genes. Appl Environ Microbiol. 2013;79(1):357-66.

49. van Waasbergen LG, Hildebrand M, Tebo BM. Identification and characterization of a gene cluster involved in manganese oxidation by spores of the marine Bacillus sp. strain SG-1. J Bacteriol. 1996;178(12):3517-30.

50. Lorca GL, Barabote RD, Zlotopolski V, Tran C, Winnen B, Hvorup RN, et al. Transport capabilities of eleven gram-positive bacteria: comparative genomic analyses. Biochim Biophys Acta. 2007;1768(6):1342-66.

51. Qasem-Abdullah H, Perach M, Livnat-Levanon N, Lewinson O. ATP binding and hydrolysis disrupt 
the high-affinity interaction between the heme $A B C$ transporter HmuUV and its cognate substrate-binding protein. J Biol Chem. 2017;292(35):14617-24.

52. Volpon L, Young CR, Matte A, Gehring K. NMR structure of the enzyme GatB of the galactitol-specific phosphoenolpyruvate-dependent phosphotransferase system and its interaction with GatA. Protein Sci. 2006;15(10):2435-41.

53. Quintero MJ, Montesinos ML, Herrero A, Flores E. Identification of genes encoding amino acid permeases by inactivation of selected ORFs from the Synechocystis genomic sequence. Genome Res. 2001;11(12):2034-40.

54. Rosario-Cruz Z, Eletsky A, Daigham NS, Al-Tameemi H, Swapna GVT, Kahn PC, et al. The copBL operon protects Staphylococcus aureus from copper toxicity: CopL is an extracellular membrane-associated copper-binding protein. J Biol Chem. 2019; 294(11):4027-44.

55. Samorodnitsky D, Nicholson EM. Differential effects of divalent cations on elk prion protein fibril formation and stability. Prion. 2018;12(1):63-71.

56. Que Q, Helmann JD. Manganese homeostasis in Bacillus subtilis is regulated by MntR, a bifunctional regulator related to the diphtheria toxin repressor family of proteins. Mol Microbiol. 2000;35(6):1454-68.

57. Chen NY, Jiang SQ, Klein DA, Paulus H. Organization and nucleotide sequence of the Bacillus subtilis diaminopimelate operon, a cluster of genes encoding the first three enzymes of diaminopimelate synthesis and dipicolinate synthase. J Biol Chem. 1993;268(13):9448-65.

58. Anandan K, Vittal RR. Endophytic Paenibacillus amylolyticus KMCLE06 extracted dipicolinic acid as antibacterial agent derived via dipicolinic acid synthetase gene. Curr Microbiol. 2019;76:178-86.

59. Shuster B, Khemmani M, Nakaya Y, Holland G, Iwamoto K, Abe K, et al. Expansion of the spore surface polysaccharide layer in Bacillus subtilis by deletion of genes encoding glycosyltransferases and glucose modification enzymes. J Bacteriol. 2019;201(19):e00321-19.

60. Fan Q, Zhang S, Gong Y, He J. Regulation of sporulation by two-component system YvcPQ in Bacillus thuringiensis. Wei Sheng Wu Xue Bao. 2017;57(1):121-30.

61. Geszvain K,Yamaguchi A, Maybee J, Tebo BM. Mn(II) oxidation in Pseudomonas putida GB-1 is influenced by flagella synthesis and surface substrate. Arch Microbiol. 2011;193:605-14.

62. Kobayashi K. Gradual activation of the response regulator DegU controls serial expression of genes for flagellum formation and biofilm formation in Bacillus subtilis. Mol Microbiol. 2007;66(2):395-409.

63. Chi L, Gao B, Bian X, Tu P, Ru H, Lu K. Manganese-induced sex-specific gut microbiome perturbations in C57BL/6 mice. Toxicol Appl Pharmacol. 2017;331:142-53.

64. Hou Y, Cheng K, Li Z, Ma X, Wei Y, Zhang L, et al. Biosorption of cadmium and manganese using free cells of Klebsiella sp. isolated from waste water. PLoS One. 2018;13(5):e0198309.

65. Weisburg WG, Barns SM, Pelletier DA, Lane DJ. 16S ribosomal DNA amplification for phylogenetic study. J Bacteriol. 1991;173:697-703.

66. Johnson HA, Tebo BM. In vitro studies indicate a quinone is involved in bacterial $\mathrm{Mn}$ (II) oxidation. Arch Microbiol. 2008;189:59-69.

67. Bohu T, Santelli CM, Akob DM, Neu TR, Ciobota V, Rösch P, et al. Characterization of pH dependent $\mathrm{Mn}(\mathrm{II})$ oxidation strategies and formation of a bixbyite-like phase by Mesorhizobium australicum T-G1. Front Microbiol. 2015;6:734.

68. Haas BJ, Papanicolaou A, Yassour M, Grabherr M, Blood PD, Bowden J, et al. De novo transcript sequence reconstruction from RNA-seq using the Trinity platform for reference generation and analysis. Nat Protoc 2013;8:1494-512.

69. Livak KJ, Schmittgen TD. Analysis of relative gene expression data using real-time quantitative PCR and the 2(-Delta Delta C(T)) Method. Methods. 2001;25:402-8. 
70. Tang LT, Ran XQ, Mao N, Zhang FP, Niu X, Ruan YQ, et al. Analysis of alternative splicing events by RNA sequencing in the ovaries of Xiang pig at estrous and diestrous. Theriogenology. 2018;119:60-8.

\section{Figure and Table Legends}

\section{Figure legends}

Fig. 1 The oxidation capacity of Mn(II) by strain ST7 detected by LBB method.

Fig. 2 The oxidation of strain ST7 in liquid medium detected by LBB solution.

Fig. 3 The precipitates of manganese oxides outside of bacteria by SEM observation.

Fig. 4 Detection for the motility of bacteria ST7 under manganese stress.

Fig. 5 The growth curves of strain ST7 at different concentrations of manganese stress.

Fig. 6 The different expressed genes of strain ST7.

Fig. 7 The high-quality expressed genes between two stages.

Fig. 8 The variable gene numbers based on KEGG enrichment hierarchy at stage 2 compared with that of stage 1.

Fig. 9 The pattern of expressed genes confirmed by RT-qPCR method cultured in media supplied with $250 \mathrm{mg} / \mathrm{L} \mathrm{Mn(II)}$.

Fig. 10 Determination for the manganese oxidation ability of mutant $\Delta$ gene601.

\section{Table legends}

Table 1 The statistical statement of transcriptome sequencing of $B$. safensis strain ST7.

Table 2 High expressed DEGs enriched in KAAS pathway of strain ST7 in stage 1.

Table 3 The expressed gene related with flagellum at two stages of strain ST7.

\section{Supplement information}

\section{Additional files 1:}

Fig. S1 The Gram staining is positive (A) and the endospore (B) producing in strain ST7.

Fig. S2 The phylogenetic trees constructed using MEGA7.

Fig. S3 Alignment of the amino acids sequence encoded by gene601 of strain ST7 with other proteins with manganese oxidation activity confirmed by experiments.

Fig. S4 The amplification and standard curve for representative transcripts taking the positive recombinant plasmids as templates. 


\section{Additional files 2:}

Table S1. The different expressed genes under manganese stress in stage 1 of Bacillus safensis strain ST7.

Table S2. The candidate genes related with manganese stress in stage 1.

Table S3. The candidate genes related with manganese stress in stage 2.

Table S4. Genes with great change between two stages.

Table S5. Great changed genes enriched in KAAS pathway in stage 2 compared with that in stage 1 of strain ST7.

Table S6. Primers for detection of gene expression by RT-qPCR. 
Table 2 High expressed DEGs enriched in KAAS pathway of strain ST7 in stage 1

\begin{tabular}{lllll}
\hline KAAS hierarchy & KO number & Protein in KEGG & gene-ID & logFC \\
\hline A09100 & & Gene product
\end{tabular}

A09100 Metabolism

B 09105 Amino acid metabolism

C 00310 Lysine degradation [PATH:ko00310]

WP_073204667.1 K03897 iucD lysine N6-hydroxylase $\quad$ [EC:1.14.13.59] $\quad$ gene1073 $4.54 \quad$ lysine 6-monooxygenase

B 09108 Metabolism of cofactors and vitamins

C 00860 Porphyrin and chlorophyll metabolism [PATH:ko00860]

WP_073207903.1 K07145 isdG, isdl heme $\quad$ oxygenase $\quad$ (staphylobilin-producing) gene3829 $4.10 \quad$ iron ABC transporter ATP-binding protein

A09130 Environmental Information Processing

B 09132 Signal transduction

C 02020 Two-component system [PATH:ko02020]

WP 024424158.1 K03407 cheA two-component system, chemotaxis family, sensor gene1591 kinase CheA [EC:2.7.13.3]

4.25 chemotaxis protein CheA

A09140 Cellular Processes

B 09142 Cell motility

C 02030 Bacterial chemotaxis [PATH:ko02030]

WP_024424158.1 K03407 cheA two-component system, chemotaxis family, sensor gene1591 kinase CheA [EC:2.7.13.3]

\begin{tabular}{|c|c|c|c|}
\hline WP_024424766.1 & gene1413 & 6.01 & hypothetical protein \\
\hline WP_073208444.1 & gene3837 & 4.04 & heme uptake protein IsdC \\
\hline WP_073207942.1 & gene3838 & 4.09 & cell surface protein \\
\hline WP_073207923.1 & gene3836 & 4.12 & sortase B protein-sorting domain-containing protein \\
\hline WP_024425256.1 & gene784 & 4.15 & hypothetical protein \\
\hline WP_073204669.1 & gene1074 & 4.47 & lucA/lucC family siderophore biosynthesis protein \\
\hline
\end{tabular}


Table 3 The expressed gene related with flagellum at two stages of strain ST7.

\begin{tabular}{|c|c|c|c|c|c|c|}
\hline & Stage 1 logFC & up/c & n product & Path/hierarchy & Mean1(ctrl) & Mean2 $(\mathrm{Mg}(\mathrm{II}))$ \\
\hline 1 & gene1579 3.92 & up & flagellar motor switch protein FliM & $\begin{array}{l}\text { Flagellar assembly path [ko02040]; Chemotaxis } \\
\text { [ko02030] }\end{array}$ & path 551.88 & 8432.12 \\
\hline 2 & gene15834.00 & up & flagellar biosynthetic protein FliP & Flagellar assembly path [ko02040] & 214.82 & 3480.70 \\
\hline 3 & gene1585 3.91 & up & flagellar type III secretion system protein FliF & Flagellar assembly path [ko02040] & 220.36 & 3360.18 \\
\hline 4 & gene1582 3.92 & up & flagella biosynthesis protein FliZ & Flagellar assembly path [ko02040] & 287.57 & 4414.79 \\
\hline 5 & gene1576 3.53 & up & flagellar basal-body rod protein FlgF & Flagellar assembly path [ko02040] & 497.13 & 5796.93 \\
\hline 6 & gene1575 3.81 & up & flagellar hook assembly protein FlgD & Flagellar assembly path [ko02040] & 199.50 & 2813.12 \\
\hline 7 & gene1578 3.69 & up & flagellar basal body-associated protein FliL & Motility hierarchy [BR:ko02035] & 225.87 & 2929.66 \\
\hline 8 & gene1580 4.00 & up & flagellar motor switch phosphatase FliY & $\begin{array}{l}\text { Flagellar assembly path [ko02040]; Chemotaxis } \\
\text { [ko02030] }\end{array}$ & ${ }_{446.05}$ & 7154.77 \\
\hline 9 & gene1571 3.35 & up & flagellar protein export ATPase Flil & Flagellar assembly path [ko02040] & 723.64 & 7423.43 \\
\hline 10 & gene1588 3.50 & up & flagellar biosynthesis protein FlhF & Motility hierarchy [BR:ko02035] & 245.33 & 2820.23 \\
\hline 11 & gene1572 3.27 & up & flagellar export protein FliJ & Flagellar assembly path [ko02040] & 183.60 & 1790.97 \\
\hline 12 & gene1565 2.87 & up & flagellar basal body rod protein FlgB & Flagellar assembly path [ko02040] & 333.57 & 2446.63 \\
\hline 13 & gene1574 3.49 & up & flagellar hook-length control protein & Flagellar assembly path [ko02040] & 654.93 & 7377.37 \\
\hline 14 & gene1567 3.04 & up & $\begin{array}{l}\text { flagellar hook-basal body complex proteir } \\
\text { FliE }\end{array}$ & Flagellar assembly path [ko02040] & 226.49 & 1851.32 \\
\hline 15 & gene1568 3.02 & up & flagellar basal body M-ring protein FliF & Flagellar assembly path [ko02040] & 1533.75 & 12509.32 \\
\hline 16 & gene1570 3.23 & up & flagellar assembly protein FliH & Flagellar assembly path [ko02040] & 444.29 & 4174.92 \\
\hline 17 & gene1587 2.60 & up & flagellar biosynthesis protein FlhA & Flagellar assembly path [ko02040] & 671.68 & 4107.13 \\
\hline 18 & gene1566 2.88 & up & flagellar basal body rod protein FlgC & Flagellar assembly path [ko02040] & 285.76 & 2101.16 \\
\hline 19 & gene1569 2.83 & up & flagellar motor switch protein FliG & $\begin{array}{l}\text { Flagellar assembly path [ko02040]; Chemotaxis } \\
\text { [ko02030] }\end{array}$ & path $_{952.20}$ & 6763.78 \\
\hline 20 & gene3527 2.19 & up & flagellar hook-associated protein FlgL & Flagellar assembly path [ko02040] & 285.80 & 1316.91 \\
\hline 21 & gene1584 2.99 & up & flagellar biosynthetic protein FliQ & Flagellar assembly path [ko02040 & 67.05 & 549.11 \\
\hline 22 & gene3522 2.02 & up & flagellar capping protein & Flagellar assembly path [ko02040] & 138.68 & 569.47 \\
\hline 23 & gene3521 1.92 & up & flagella export chaperone Flis & Flagellar assembly path [ko02040] & 120.00 & 463.46 \\
\hline
\end{tabular}




\begin{tabular}{|c|c|c|c|c|c|c|}
\hline 24 & gene3520 1.64 & up & flagellar protein FliT & Flagellar assembly path [ko02040] & 186.17 & 588.67 \\
\hline 25 & gene1206 2.40 & up & flagellin & Flagellar assembly path [ko02040] & 275.39 & 1475.83 \\
\hline 26 & gene3528 1.71 & up & flagellar hook-associated protein FlgK & Flagellar assembly path [ko02040] & 675.41 & 2227.98 \\
\hline 27 & gene3529 1.40 & up & flagellar protein FlgN & & 206.35 & 551.20 \\
\hline 28 & gene1306 1.25 & up & flagellar motor protein MotB & $\begin{array}{l}\text { Flagellar assembly path [ko02040]; Chemotaxis } \\
\text { [ko02030 }\end{array}$ & path $_{308.83}$ & 746.97 \\
\hline 29 & gene1307 1.64 & up & flagellar motor stator protein MotA & $\begin{array}{l}\text { Flagellar assembly path [ko02040]; Chemotaxis } \\
\text { [ko02030] }\end{array}$ & path 210.07 & 669.28 \\
\hline 30 & gene3617 1.03 & up & flagellar hook-basal body protein & Flagellar assembly path [ko02040] & 1464.66 & 2999.27 \\
\hline 31 & gene1207 1.01 & up & flagellin & Flagellar assembly path [ko02040] & 116.42 & 235.75 \\
\hline 32 & gene3530 1.10 & up & flagellar biosynthesis anti-sigma factor FlgM & Flagellar assembly path [ko02040] & 160.19 & 346.71 \\
\hline 33 & gene3523 0.96 & no-diff & flagellar biosynthesis protein FlaG & Motility hierarchy [BR:ko02035] & 104.49 & 207.72 \\
\hline & Stage 2 logFC & \multicolumn{2}{|c|}{ up/down product } & Path/hierarchy & Mean3(ctrl) & Mean4 $(\mathrm{Mg}(\mathrm{II}))$ \\
\hline 1 & gene1307 -3.63 & down & flagellar motor stator protein MotA & $\begin{array}{l}\text { Flagellar assembly path [ko02040]; Chemotaxis } \\
\text { [ko02030] }\end{array}$ & path 2240.93 & 178.20 \\
\hline 2 & gene3522 -2.19 & down & flagellar capping protein & Flagellar assembly path [ko02040] & 374.19 & 78.89 \\
\hline 3 & gene3521 -2.12 & down & flagella export chaperone FliS & Flagellar assembly path [ko02040] & 392.19 & 83.70 \\
\hline 4 & gene1306 -1.95 & down & flagellar motor protein MotB & $\begin{array}{l}\text { Flagellar assembly path [ko02040]; Chemotaxis } \\
\text { [ko02030] }\end{array}$ & path 1096.31 & 277.47 \\
\hline 5 & gene3520 -1.79 & down & flagellar protein FliT & Flagellar assembly path [ko02040] & 242.38 & 64.98 \\
\hline 6 & gene1582 -1.66 & down & flagella biosynthesis protein FliZ & Flagellar assembly path [ko02040] & 3590.08 & 1105.95 \\
\hline 7 & gene1584 -1.62 & down & flagellar biosynthetic protein FliQ & Flagellar assembly path [ko02040] & 260.70 & 83.87 \\
\hline 8 & gene1580 -1.56 & down & flagellar motor switch phosphatase FliY & $\begin{array}{l}\text { Flagellar assembly path [ko02040]; Chemotaxis } \\
\text { [ko02030] }\end{array}$ & ${ }_{4661.73}$ & 1487.77 \\
\hline 9 & gene1571 -1.28 & down & flagellar protein export ATPase Flil & Flagellar assembly path [ko02040] & 4616.94 & 1839.53 \\
\hline 10 & gene1206 1.08 & up & flagellin & Flagellar assembly path [ko02040] & 1981.35 & 3999.85 \\
\hline 11 & gene1178 2.05 & up & flagellin & Flagellar assembly path [ko02040] & 330.26 & 1310.52 \\
\hline
\end{tabular}


Figures

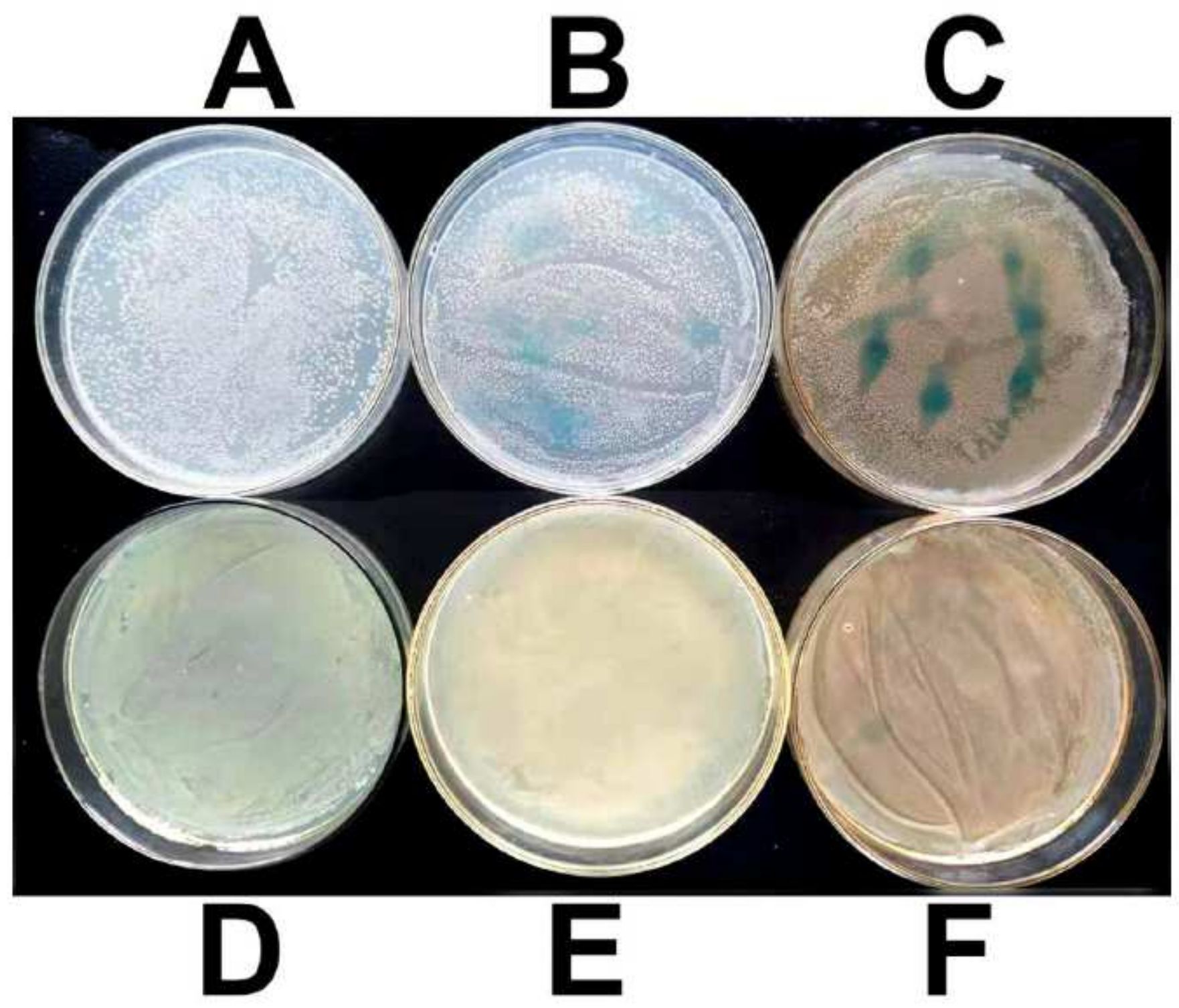

Figure 1

The oxidation capacity of $\mathrm{Mn}$ (II) by strain ST7 detected by LBB method. 


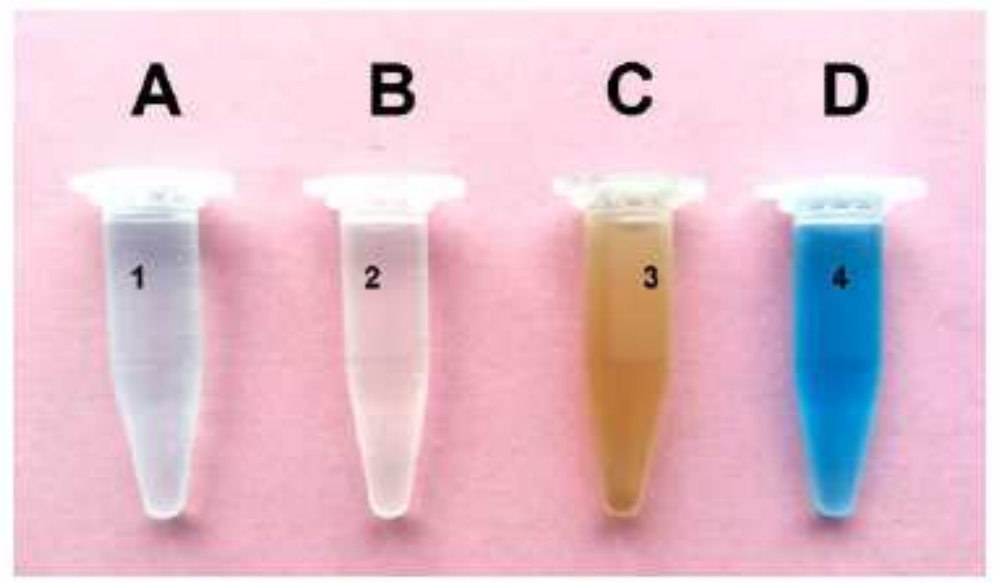

Figure 2

The oxidation of strain ST7 in liquid medium detected by LBB solution.
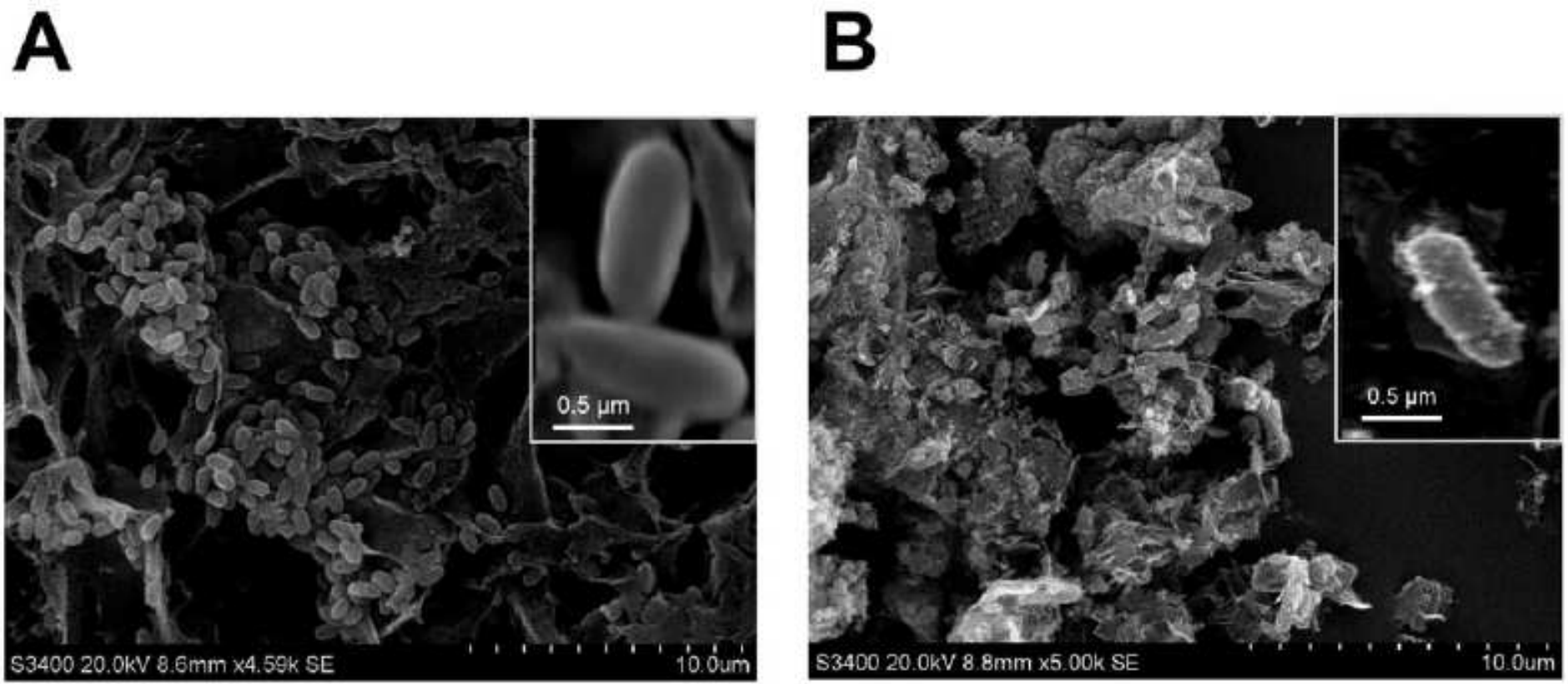

\section{Figure 3}

The precipitates of manganese oxides outside of bacteria by SEM observation. The strain ST7 bacteria were cultivated for seven days in PYCM liquid media without Mn(II) (A) or supplied with $2200 \mathrm{mg} / \mathrm{L}$ $\mathrm{MnCl} 2(\mathrm{~B})$. 

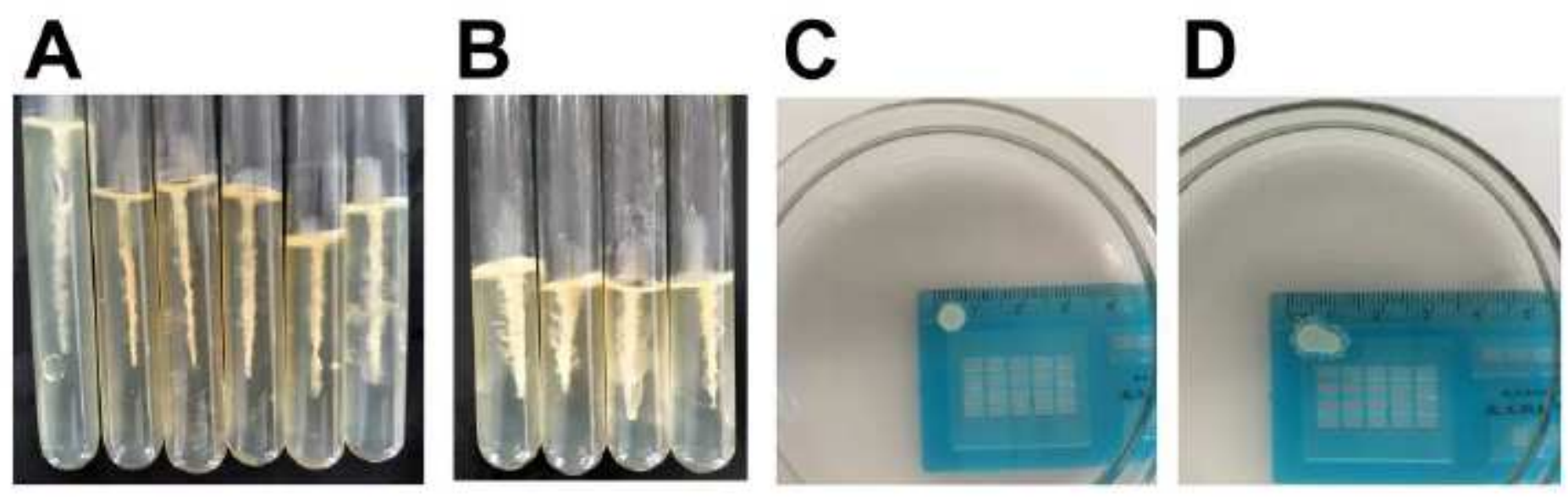

\section{Figure 4}

Detection for the motility of bacteria ST7 under manganese stress. A: Punctured tube of strain ST7 without Mn(II) supply. B: Punctured tube of strain ST7 with $250 \mathrm{mg} / \mathrm{L} \mathrm{Mn}$ (II). C: Soft-agar plate of strain ST7 without Mn(II) supply. D: Soft-agar plate of strain ST7 with $250 \mathrm{mg} / \mathrm{L} \mathrm{Mn(II)}$

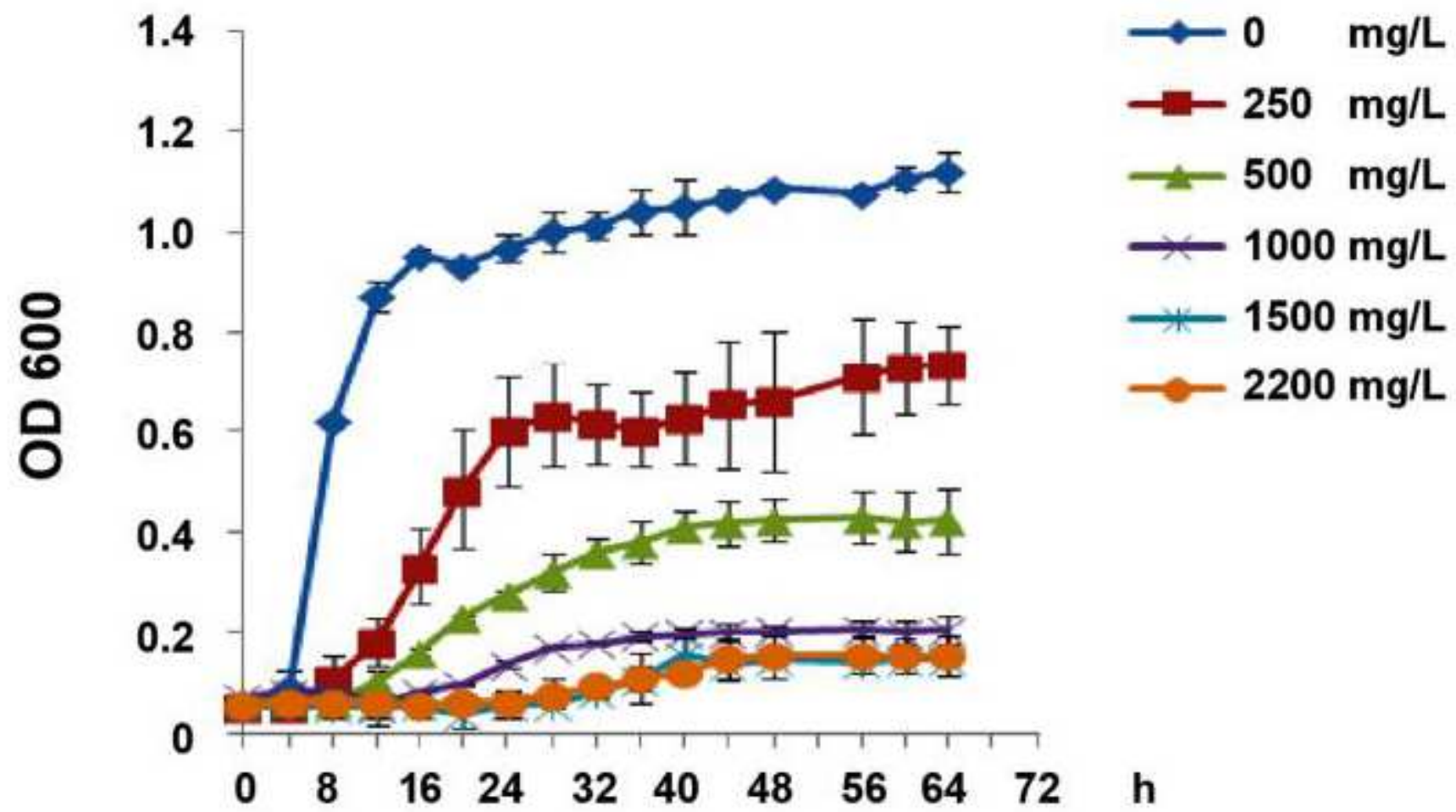

Figure 5

The growth curves of strain ST7 at different concentrations of manganese stress. 

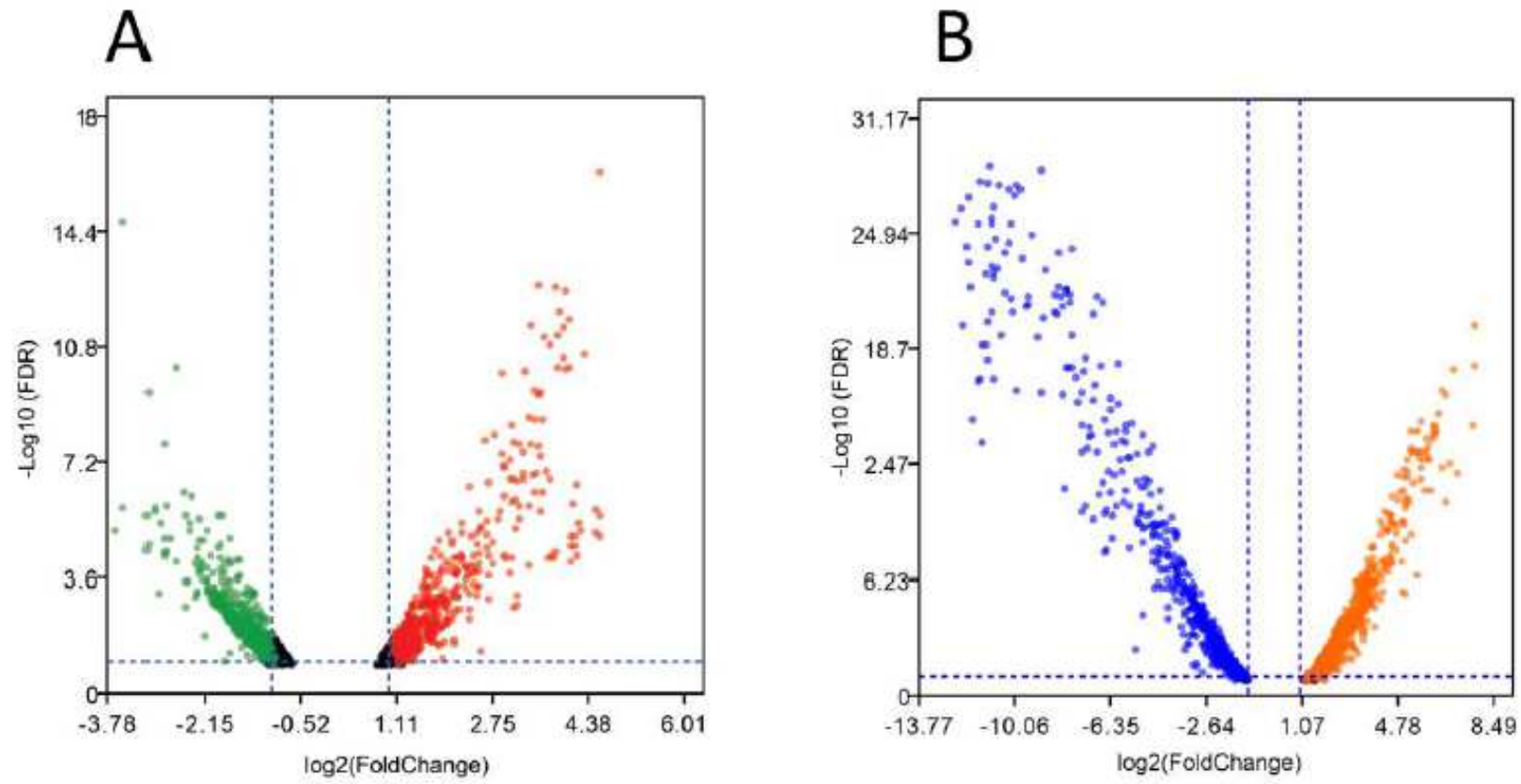

Figure 6

The different expressed genes of strain ST7.

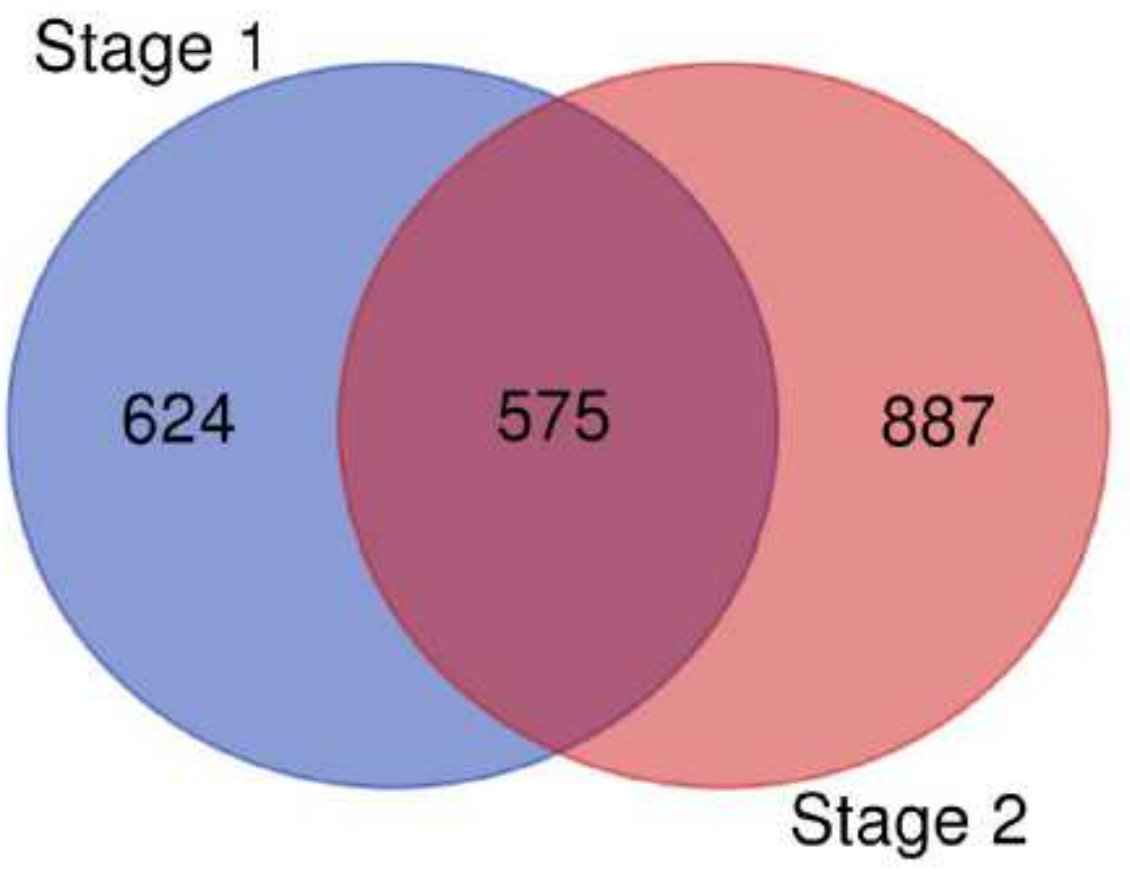

Figure 7

The high-quality expressed genes between two stages. 


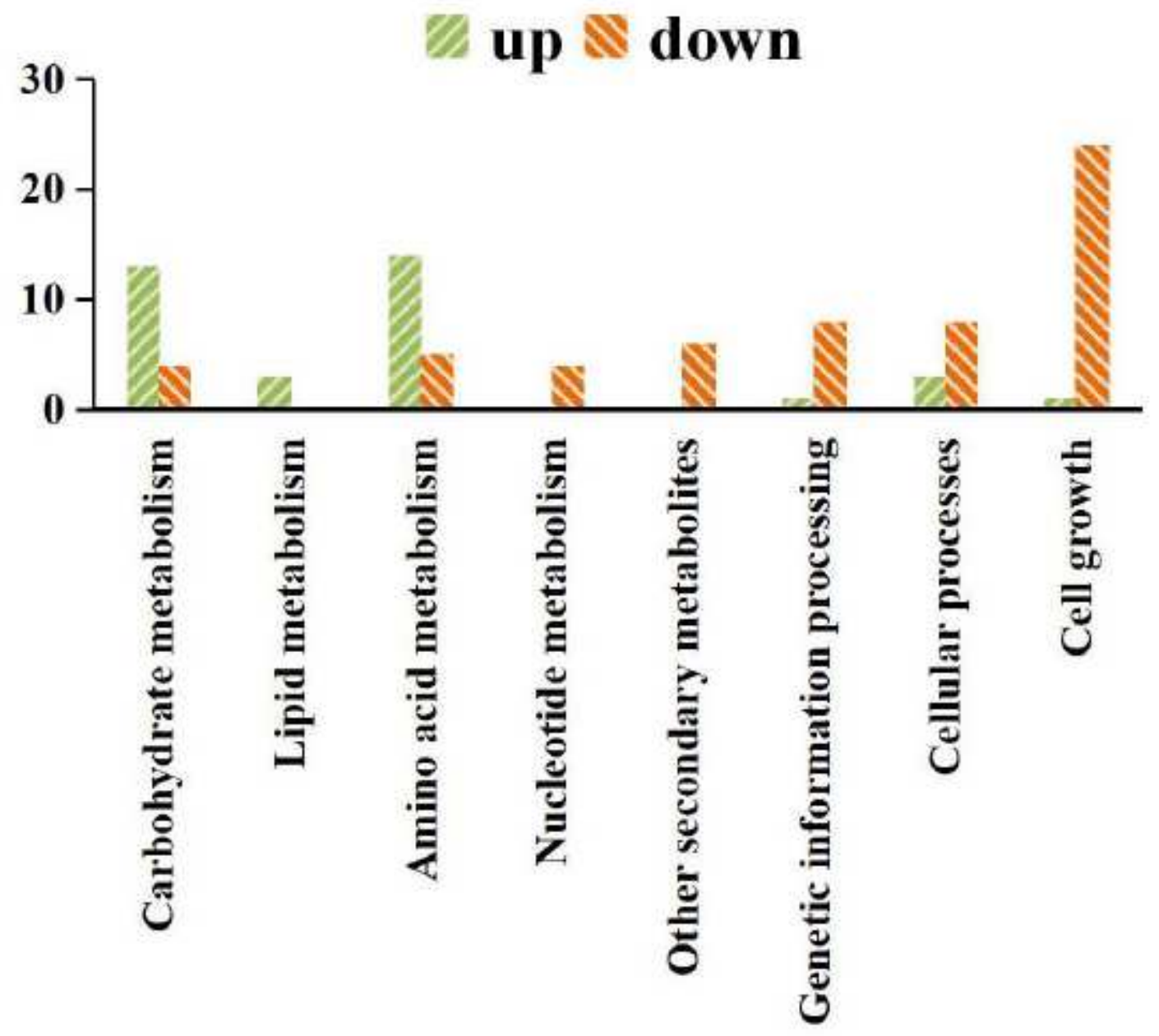

Figure 8

The variable gene numbers based on KEGG enrichment hierarchy at stage 2 compared with that of stage 1. 


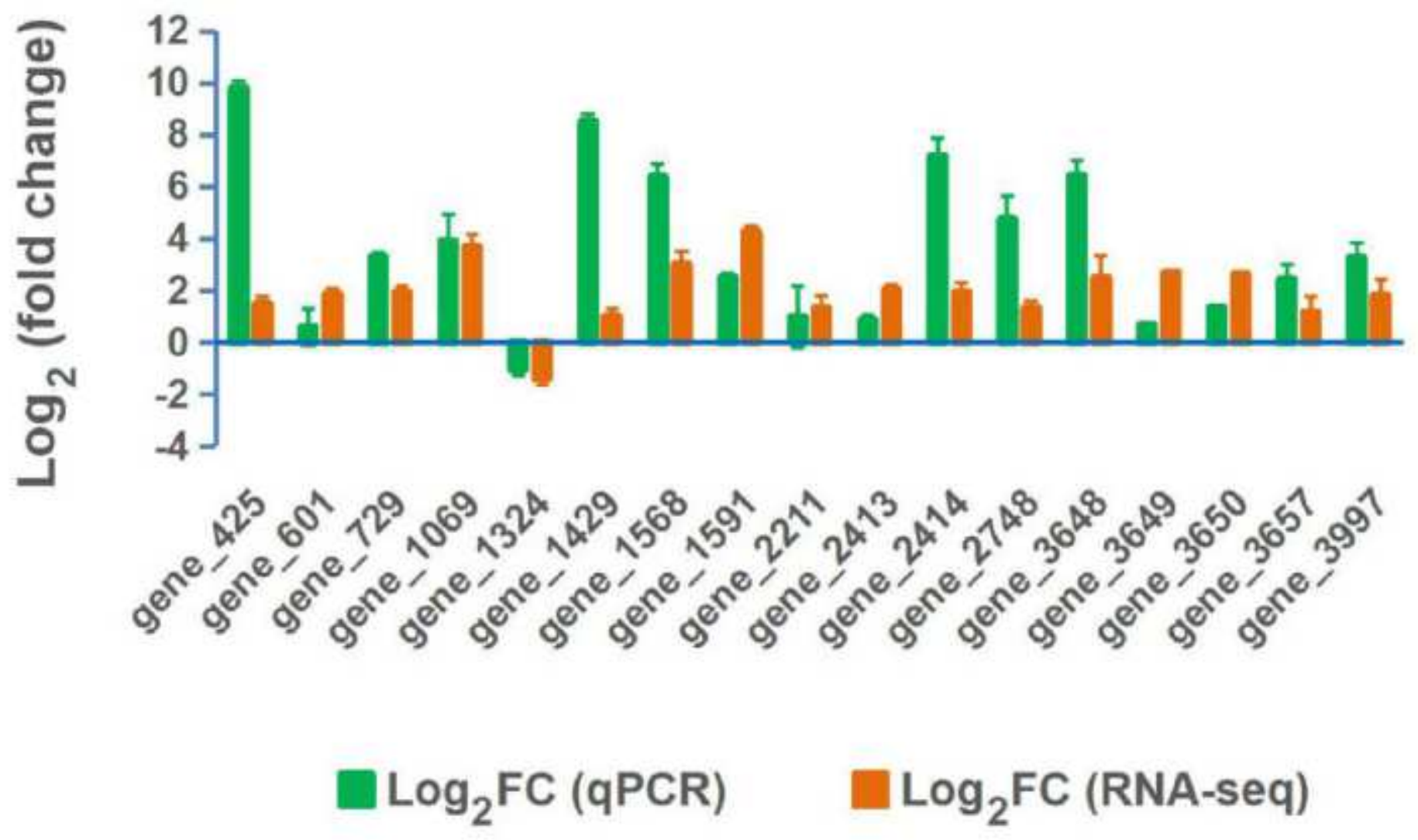

Figure 9

The pattern of expressed genes confirmed by RT-qPCR method cultured in media supplied with $250 \mathrm{mg} / \mathrm{L}$ $\mathrm{Mn}(\mathrm{II})$.
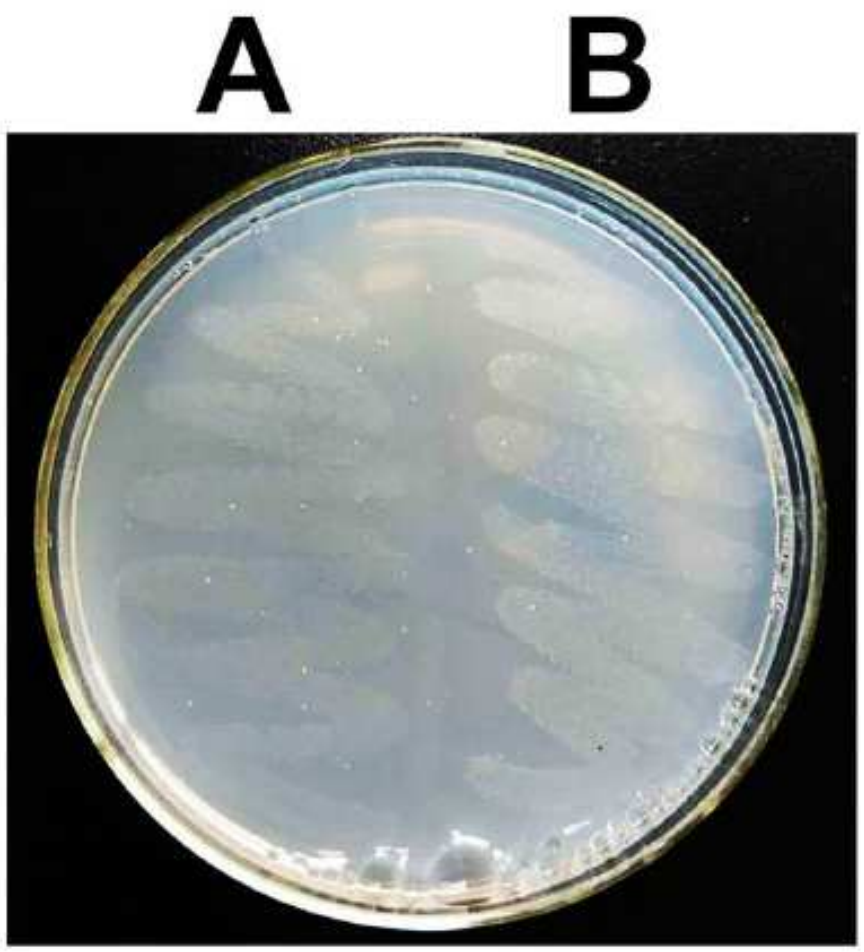

C

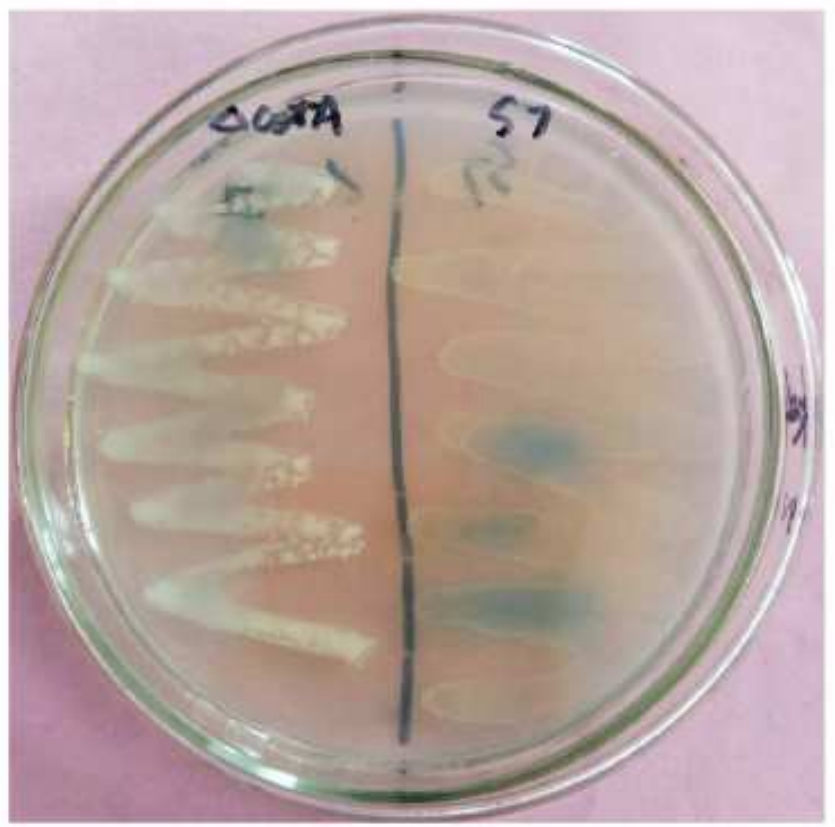


Figure 10

Determination for the manganese oxidation ability of mutant $\Delta$ gene601. Both of the mutant $\Delta$ gene601 and wild strain ST7 were cultivated on PYCM media plate with $250 \mathrm{mg} / \mathrm{L} \mathrm{Mn(II).} \mathrm{A:} \mathrm{the} \mathrm{mutant} \Delta$ gene601 cultivated for $16 \mathrm{hs}$. B: wild strain ST7 cultivated for $16 \mathrm{hs.} \mathrm{C:} \mathrm{the} \mathrm{mutant} \Delta$ gene601 cultivated for seven days. D: wild strain ST7 cultivated for seven days.

\section{Supplementary Files}

This is a list of supplementary files associated with this preprint. Click to download.

- supplementFigs14.pdf

- supplementFigs14.pdf

- TableS1DEGoffourgroups.xls

- TableS1DEGoffourgroups.xls

- Tables2stage1.xls

- Tables2stage1.xls

- TableS3stage2.xls

- TableS3stage2.xls

- Tables4Twostages.xls

- Tables4Twostages.xls

- Tables5.xls

- Tables5.xls

- Tables6primers.xls

- TableS6primers.xls 